\title{
The Godwins, Towns and St Olaf Churches: Comital Investment in the Mid-nth Century
}

\author{
Robert Higham
}

Historical research into the late Old English ruling class has been much pursued in recent decades. This essay brings together two of the many major themes emerging from recent work: aristocratic interest in towns and aristocratic church patronage. Their importance-singly, or in conjunction-has been highlighted, in different ways, by a number of authors. ${ }^{1}$ Here, they are brought together in order to explore possible links between the urban interests of the Godwin family and the building of churches dedicated to St Olaf in Exeter, Chichester and Southwark. This study arises from another enquiry concerning evidence for a comital residence in Exeter in the mid-11th century. This was located in the north-west quarter of Exeter, not far from the church of St Olaf (known as St Olave's, as elsewhere, from the Latin form of the name). This property was remembered in local tradition and gave rise to the name Irlesbery (in various spellings), found in sources of late 12th-century and later date. Outer (northern) parts of Irlesbery became the site of a hospital (St Alexius) in the late 12th century. The endowment of the church of St Olaf in Exeter was linked with the Godwins and with Edward the Confessor. Traditions of these endowments survive in a later cartulary of St Nicholas Priory, a Benedictine house founded by Battle Abbey (Sussex). William the Conqueror gave St Olave's church to Battle by the time of the Domesday survey. The priory, which soon developed immediately adjacent, occupied the central (southerly) part of Irlesbery which, after the Conquest, passed into royal hands. The documentary evidence (hitherto unpublished and complex) for this comital property, its assessment in Exeter's urban topography and its links with St Olave's church, are

1 Gervase Rosser, "The Cure of Souls in Engish Towns before 1000," in Pastoral Care before the Parish, ed. John Blair and Richard Sharpe (Leicester, 1992), pp. 267-84; Robin Fleming, "Rural Elites and Urban Communities in Late Saxon England," Past and Present 141 (1993), 3-37; Ann Williams, "Thegnly Piety and Ecclesiastical Patronage in the Late Old English Kingdom," ANS 24 (2002), 1-24; John Blair, The Church in Anglo-Saxon Society (Oxford, 2005); Oliver Creighton and Robert Higham, Medieval Town Walls. An Archaeology and Social History (Stroud, 2005); Stephen Baxter, The Earls of Mercia. Lordship and Power in Late Anglo-Saxon England (Oxford, 2007). 
the subject of a study published separately. ${ }^{2}$ In what follows, the existence of this property, including a church which has survived and a residence which has not, has been assumed. ${ }^{3}$

In the present context (Fig. 23.1), what matters is the tradition of the endowment of the church by the Godwins because, looking further afield, we also find St Olaf's churches in two other towns in whose territories the Godwins were highly influential: Chichester, in Sussex and Southwark, on the south bank of the Thames opposite London. Although in Chichester and Southwark, the link between the St Olaf churches and the Godwins is less explicit than is the case in Exeter, it is suggested in what follows that the three places illuminate a largely unrecognised aspect of the church patronage of this most powerful of 11thcentury families. The best-known associations of the Godwins and churches relate to collegiate foundations rather than to lesser churches. The family also had a reputation for despoiling churches, but how far this was deserved or simply a product of later anti-Godwin propaganda is unclear. Earl Godwin may have re-founded the minster at Dover (Kent) as a college of secular canons, moving it from near the shore to the higher, defended area above the town. By the time of Domesday there were twenty-four canons there. In Henry I's reign, it was moved again back into the town. ${ }^{4}$ In 106o, Earl Harold, Godwin's son, founded a college of secular canons at Waltham (Essex), a church with an already-long history. ${ }^{5}$ Edward the Confessor's queen, Edith, Godwin's daughter, re-built Wilton Abbey (Wiltshire), where she was educated. ${ }^{6}$

In embracing notions of territorial power, the ruling class, towns and a popular north European saint, this exploration of the Godwins and some St Olaf churches will hopefully address the theme of the book in which it is offered, with much personal affection and professional respect, to its dedicatee.

2 Robert Higham, "Earlsbury: A Comital Residence in Exeter," Proceedings of Devon Archaeological Society 76 (2018), 141-85.

3 Given the overlapping subject-matter, repetition of some data in the two studies has been unavoidable. I am grateful to the Devon Archaeological Society for consideration in this matter. For the background to Exeter in this period see: John Allan, Christopher Henderson, and Robert Higham, "Saxon Exeter," in Anglo-Saxon Towns in Southern England, ed. Jeremy Haslam (Chichester, 1984), pp. 385-411; Robert Higham, Making Anglo-Saxon Devon: Emergence of a Shire (Exeter, 2008); Robert Higham, "William the Conqueror's Siege of Exeter in 1068," Transactions of the Devonshire Association 145 (2013), 93-132.

4 Williams, "Thegnly Piety and Ecclesiastical Patronage," p. 8 and sources quoted there.

5 Williams, "Thegnly Piety and Ecclesiastical Patronage," p. 14.

6 Frank Barlow, The Godwins: The Rise and Fall of a Noble Dynasty (Harlow, 2002), pp. 107-11; Emma Mason, The House of Godwine. The History of a Dynasty (London, 2004), pp. 84-87. 


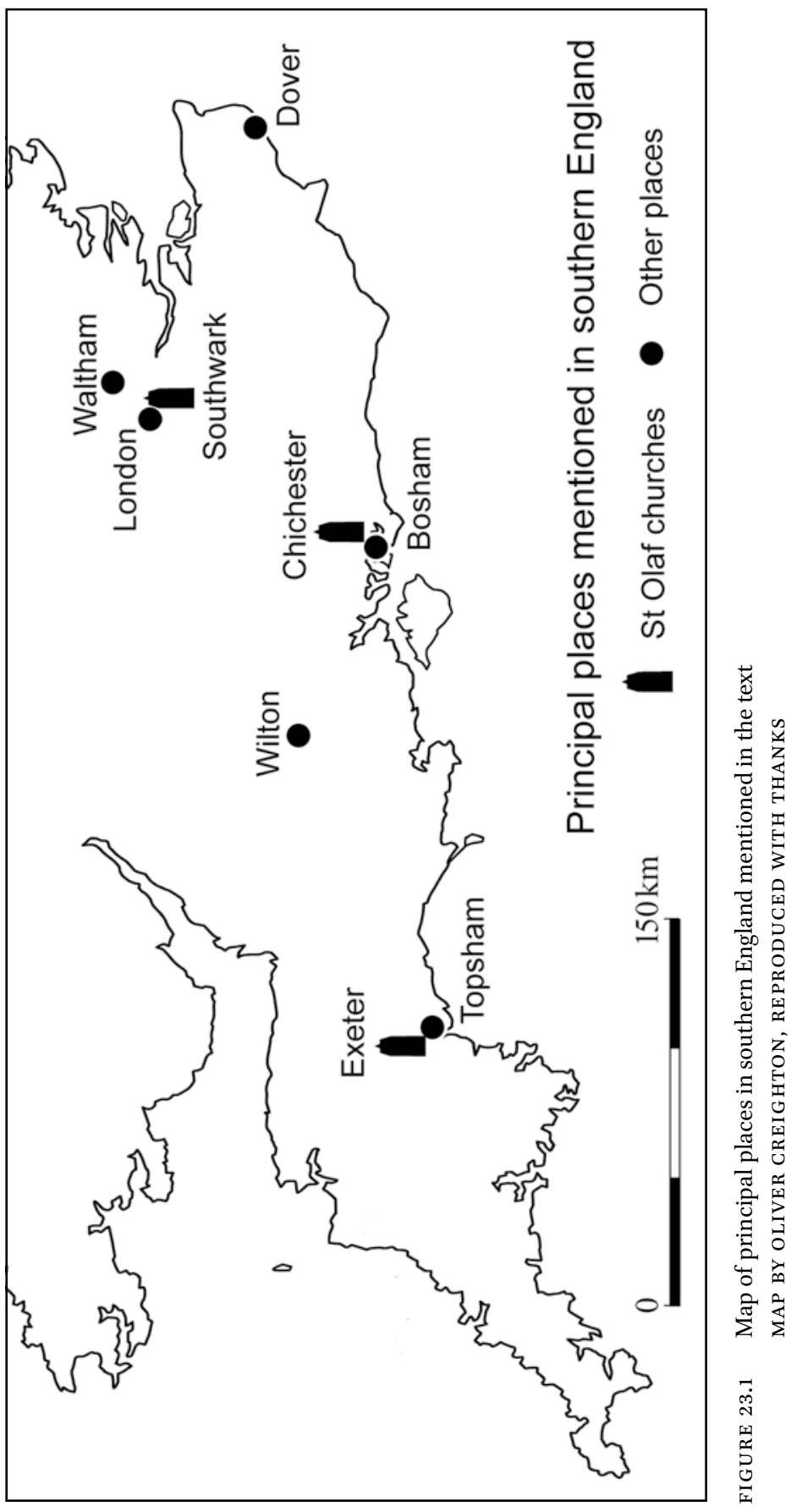




\section{St Olaf-King and Saint}

The saint to whom the church in Exeter was (amongst others: see below) dedicated, whose name in English-speaking regions became "Olave" (and sometimes, through the pronouncing of St and Olave together, Tooley) was the Norwegian king, Olaf Haraldsson, born in 995, reigned 1016-1029 and died in 1030. ${ }^{7}$ After a warrior career in the Baltic, northern France and England-including service for Æthelred II of England against the Danes-he returned to Norway and seized power as king. Having adopted Christianity in England, he continued the work of King Olaf Tryggvason (ruled 995-1000, whose Christianity was also learned in England) to make Norway a fully Christian country: a process achieved partly by conversion and partly by coercion. Eventually there was an internal revolt against him, exploited and supported by Cnut, king of England and Denmark, which led to his exile in 1028-1029. In 1030, supported by Swedish allies, he attempted to recover his position but was killed in battle, on 29 July, at Stiklestad. Danish control in Norway lasted to 1035, when Cnut died. In 1035, Magnus, Olaf's own son, became king of Norway and the "Danish party" fled.

Miracles were soon reported at Olaf's grave and a chapel was built there. In August 1031, his body was moved and enshrined at St Clement's church at Nidaros, where he was declared a saint. Nidaros was soon rebuilt and became a great cathedral. From 1035, development of the cult of the new saint was assisted by the succession, as king, of his son Magnus. The Olaf cult, whose feast day was $29 \mathrm{July}$, the date of his death, thus had a political dimension as well as a dimension reflecting his role as a martyr to the Christian conversion of his country. The speedy canonisation of Olaf in Norway may have been an anti-Danish gesture, since the Danes were then ruling Norway, or-given Olaf's experience in England-it may have been influenced by the English tradition of creating royal saints. ${ }^{8}$ The cult spread rapidly in the northern world and Olaf became Norway's patron saint. He was recognised officially by the Papacy in 1164, but his sainthood had long been recognised in the wider church. In active terms of new church dedications, however, the cult lasted

7 Frances Arnold-Forster, Studies in Church Dedications or England's Patron Saints, 3 vols (London, 1899), 2:441-54; Bruce Dickins, "The Cult of St Olave in the British Isles," Saga Book of the Viking Society 12 (1937-1945), 53-80; David Hugh Farmer, The Oxford Dictionary of Saints (Oxford, 1978), pp. 300-01.

8 Sverre Bagge and Saebjørg Walaker Nordeide, "The Kingdom of Norway," in Christianization and the Rise of Christian Monarchy, ed. N. Berend (Cambridge, 2007), pp. 121-66. 
only about a century: mid-11th century to mid-12th (though there are postmedieval examples). ${ }^{9}$

In the British Isles, the Olaf cult took hold quickly. His death and subsequent canonisation were noted in the Anglo-Saxon Chronicle (MS C 1030, an annal presumably composed at a later date). His feast-day occurs in saints' calendars at several English cathedral churches, including Exeter, and at several monasteries. Representations of Saint Olaf occur in England on seals, in stained glass, woodwork and other media. Some churches dedicated to him are known to have been built before the Norman Conquest (including at York and Exeter) and others are documented later, though their foundation dates are often uncertain. The distribution of these forty-plus (rural and urban) churches in the British Isles is heavily-weighted to the Scandinavian-influenced areas of northern Britain, eastern England, the Dublin area and the northern and western isles. Further south, they occur also in a few towns: at London, Exeter and Chichester. A small number of southern English rural examples is also known. In the political confrontations of the northern world the Danes had been enemies of the Norwegians, but the cult of St Olaf soon became popular in Denmark and in Danish-influenced areas of the British Isles as well as inmore understandably — Norway and the Norse-influenced areas. This was perhaps because, until the martyrdom of King Cnut IV of Denmark in 1086 (in a rebellion not unlike that which led to Olaf's death $)^{10}$ and his canonisation by the Pope in 1101, the Danes had no national saint of their own: Olaf did, at least, represent the northern world. It has been argued that the Danish espousal of St Olaf as a saint was also a deliberately political act, aimed at adopting his influence to their own advantage in the north. ${ }^{11}$

\section{St Olave's Church, Exeter}

The church of St Olave, in Fore St, became a parish church in the early 13th century, when-along with Exeter's other lesser churches-a parochial territory was allocated to it. ${ }^{12}$ It is aligned more or less with the street, but not exactly. The building has been surveyed by Richard Parker, to whose report the

$9 \quad$ For the later cult, see Karl Alvestad, "Olavian Traces in Post-Medieval England," below, pp. 602-620.

$10 \quad$ Farmer, The Oxford Dictionary of Saints pp. 67-68.

11 Barbara Crawford, The Churches Dedicated to St Clement in Medieval England. A HagioGeography of the Seafarer's Saint in nth Century North Europe (St Petersburg, 2008), pp. $25^{-28}$ and sources quoted there.

12 Nicholas Orme, The Churches of Medieval Exeter (Exeter, 2014), pp. 28-34. 


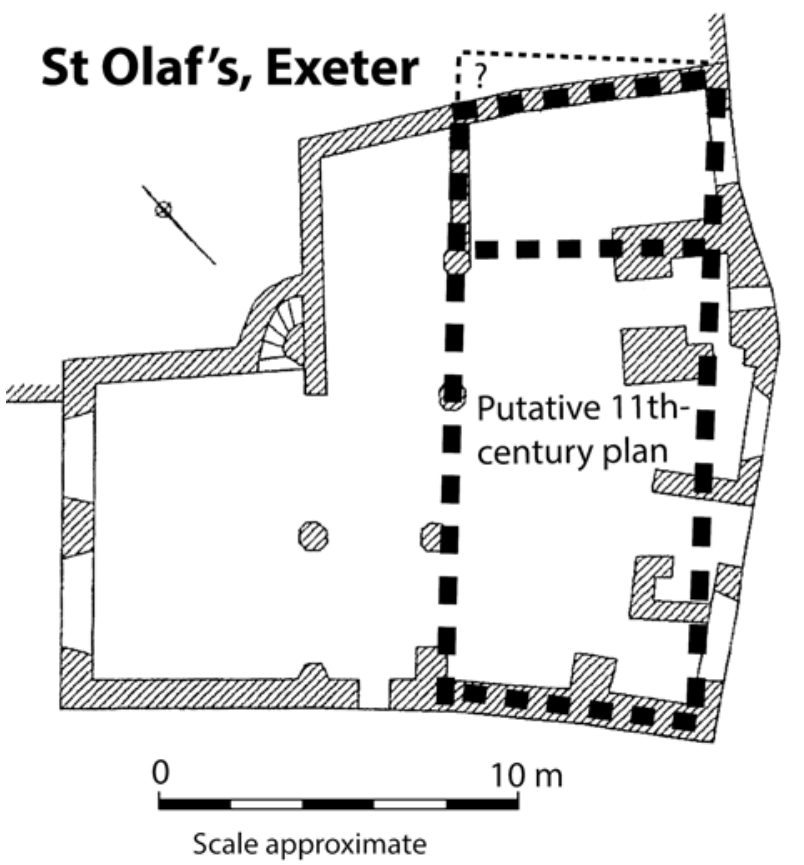

FIGURE 23.2 Plan of St Olaf's (St Olave's) church, Exeter, indicating the putative nth-century plan within the later structure. BASED, BY PERMISSION AND WITH THANKS TO ITS AUTHOR, ON THE SURVEY IN RICHARD PARKER, “ARCHAEOLOGICAL RECORDING AT ST OLAVE'S CHURCH, EXETER," FIG. 2

following discussion is indebted for some chronological and building material analysis. ${ }^{13}$ In its eventual (and current) form, it comprised a chancel, nave, two aisles on the north side, and a narrow extension on the south side which also embraces a lateral tower at the junction of nave and chancel. The two aisle

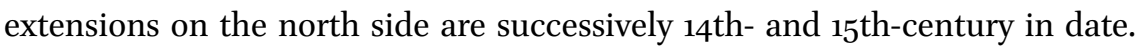
The narrow southern extension, on the Fore St side had been built by the $1750 \mathrm{os}$, since it is shown on a map of that date. ${ }^{14}$ The extension may be of 15 th-century origin (like the northernmost aisle) and related to the priest's house which is known to have been incorporated here at this time (the blocked southern

\footnotetext{
13 Richard W. Parker, "Archaeological Recording at St Olave's Church, Exeter" (unpublished Exeter Archaeology Report No. 99.67, 1999).

14 Devon Heritage Centre: Exeter City Archives, Exeter City Chamber Maps, 58/15; despite a date of 1815 given by Bridget Cherry and Nicholas Pevsner, The Buildings of England:Devon (London, 1989), p. 394.
} 


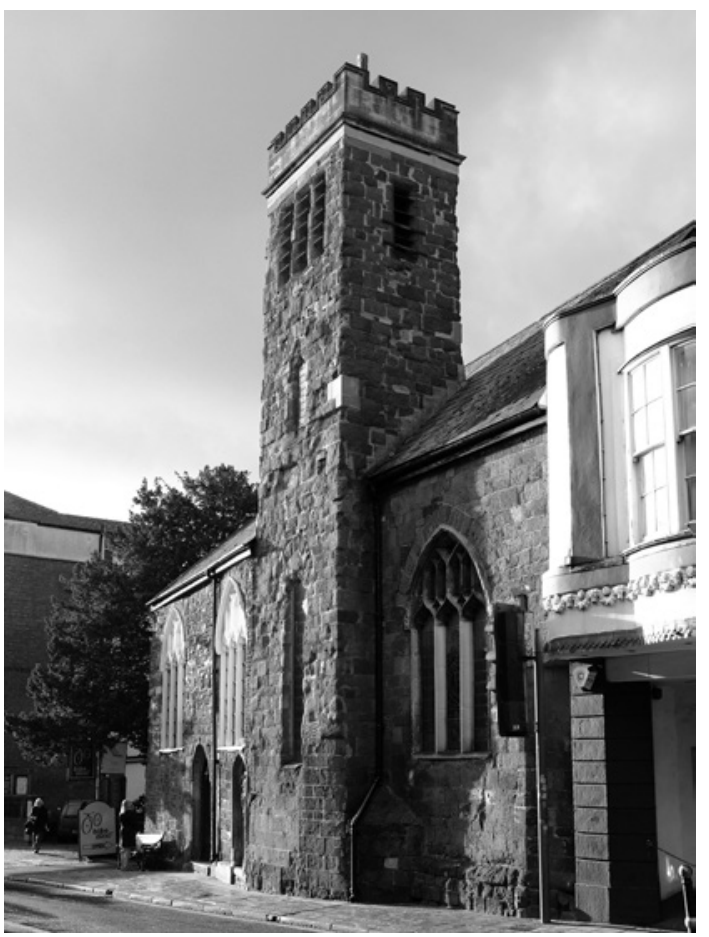

FIGURE 23.3 St Olave's church, Exeter, from the south (Fore St)

(C) AUTHOR

doorway relates to this). A wooden stair and gallery was inserted here at a later date (Figs 23.2, 23.3, 23.4).

The earliest diagnostic fabric in the building is long and short quoining of late Saxon style in the north-west external angle of the nave (abutted by the northern aisle) (Fig. 23.4). It is one of a number of churches in Exeter to retain fabric of this date: also, St Martin's (at the north-eastern edge of Cathedral Close; long and short quoins); St George's (originally on the west side of South St; fragments now re-erected on the east side of that street; long and short quoins); St Stephen's (High St; early 12th-century crypt details abut crypt walls of late Saxon date). While styles of late Saxon masonry did not immediately cease at the Norman Conquest-indeed, in Exeter, the Norman castle gatehouse contains quoins and window features of earlier style - the documentary evidence for St Olave's existence before 1066 (see below) makes it a reasonable assumption that the north-west angle of the nave is of late Saxon construction: by implication, the whole nave was of this date. The likely reconstruction of the first church is as a rectangular, two-cell (nave, chancel) plan, of locallyavailable volcanic stone with white triassic sandstone quoins, corresponding 


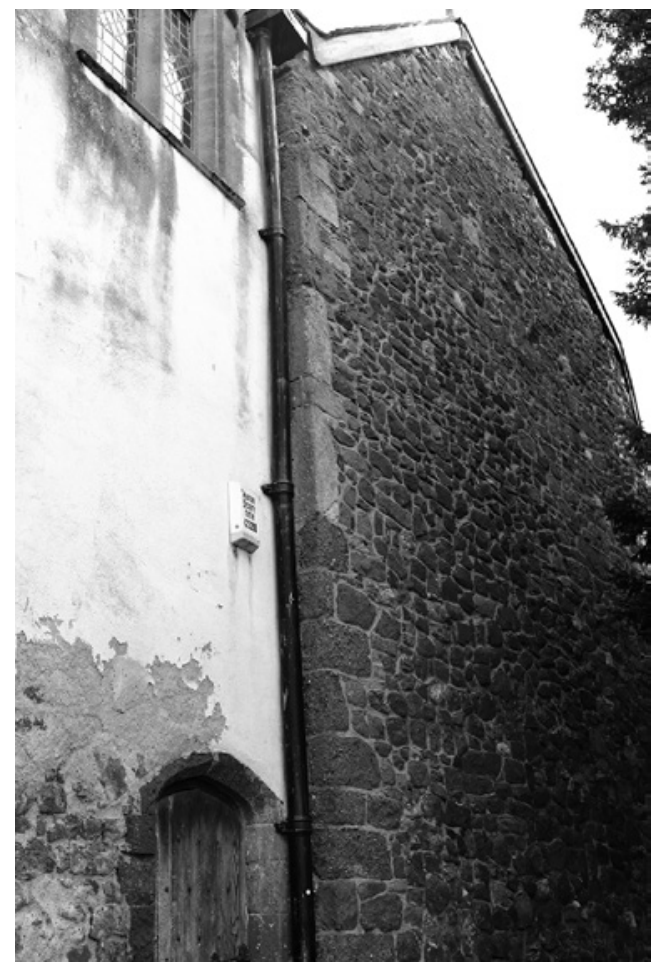

FIGURE 23.4

St Olave's church, Exeter; long-andshort quoins of primary 11th-century fabric at the west end of the nave (C) AUTHOR

to the surviving nave and chancel, approximately $7.5 \mathrm{~m}$ wide and $15 \mathrm{~m}$ long (about $25^{\prime} \times 50^{\prime}$ ). Its west wall survives and the east wall of the chancel could also be primary though it is not now available for inspection (plastered internally and con-joined with an adjacent building externally). Simple two-cell plans of this sort, in an approximate length/breadth proportion of 2:1, were normal for the city's lesser churches at this time. ${ }^{15}$ At St Olave's, the original north wall thickness is represented by the masonry supporting the west side of the nave arcade's westernmost arch (the nave arcade piers are narrower than this, and thus not remnants of the original wall, but newly-built structures). It is, however, possible that the masonry at this westernmost point suggests a north aisle arcade earlier than the existing one, perhaps of 12th-century date.

Prior to the widening of the church towards Fore Street (which destroyed any primary quoins at the south-west angle of the west end of the nave), the south tower projected from the church. Internally, its appearance has been altered by the insertion of a large arch on the north side, to open into the church, and by the insertion of a doorway in its west side to give access to a pulpit. The 


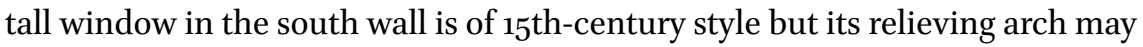
be a relic of an earlier and shorter window opening (perhaps 14th-century, the date of the ogee-headed lancet in the tower's middle storey). This large window reflects the shape of the large, internal opening: they are presumably contemporary (as also the squint). The western doorway in the tower, for the pulpit, must date from after the church was widened towards the street. Three corbels, high up on the northern (internal) face of the tower, may have supported upper timber-work (as they do now). On the exterior, the window openings suggest there were three storeys to the tower. The tower was originally topped by a spire and four pinnacles. ${ }^{16}$ The blocked southern door of the church related to the priest's house (see above). The main door was relocated outwards, perhaps from a porch, when the nave was extended towards the street. Where the 11th-century door was located is not known. It may have been on the south, as later. But since the church's origin is so closely connected with the Godwins' property which lay to its north, it is possible that the primary entrance was on the north and that the southern one was created, on the main street, when it became a parish church. A similar sequence may have applied at St Olave's, Chichester (see below).

Published comments on the date of the southern lateral tower are problematic. There is a local tradition that the lateral tower is late Saxon. ${ }^{17}$ Theoretically, the endowed nature of St Olave's (unusual for a lesser city church: see below) may have involved an embellished plan. Even allowing for later alteration of windows and other details, however, the details of the tower do not support such an early date: an addition of the later middle ages is much more likely, indeed to the point of certainty. It is constructed of high-quality squared blocks, mainly of volcanic stone, in a style which may have just-pre-dated the use of local breccia (commonly called Heavitree stone) in the city, from the late 14th century onwards. The possible influence of the mid-12th-century lateral towers of Exeter Cathedral on local churches should be considered in this context. St Petrock's (High St) and St Martin's (Cathedral Close) also had a single lateral tower. Both towers, more obviously, are of late medieval date.

\section{St Olave's Church, Exeter: Foundation and History}

Domesday Book related that the church of Battle (King William's foundation of Battle Abbey, Sussex) held the church of St Olave in Exeter in 1086 (Fig. 23.5). The name was spelt Olaf in the Exchequer Domesday; Oilaf in the main text of

16 Orme, Churches of Medieval Exeter, p. 153.

17 Cherry and Pevsner, The Buildings of England: Devon, p. 394. 


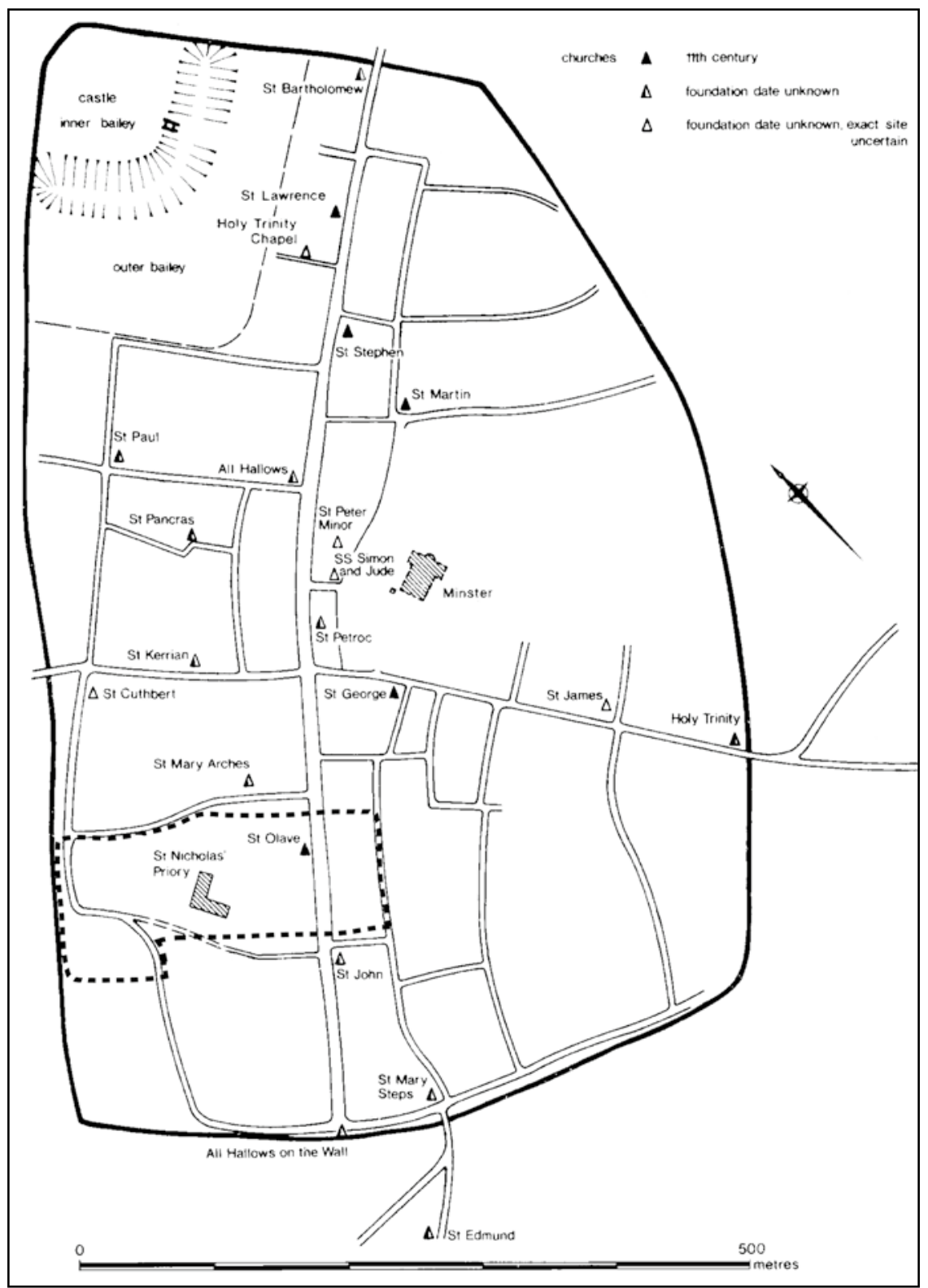

FIGURE 23.5 The 13th-century and later parish of St Olaf, Exeter (boundary simplified) and other early churches in the city.

BASED ON DATA IN ALLAN, HENDERSON \& HighaM, "SAXON EXETER,"

(FIGS 126, 128, WITH AMENDMENTS) 
the Exon Domesday and Olav in the Terrae Occupatae of Exon Domesday. ${ }^{18}$ By 1066, the Godwin family property around St Olave's already contained at least eight houses, since Battle Abbey was given eight houses in Exeter by King William with St Olave's church: the Domesday entry implies church and houses were associated. ${ }^{19}$ The only Exeter houses said by Domesday Book to have been held by the Godwins (specifically, by Earl Harold) were five attached to the rural manor of Tawstock. ${ }^{20}$ The houses later held by Battle Abbey may have been built specifically as urban properties for tenants within the area included in, or adjacent to, Irlesbery. It is, of course, possible that amongst the 285 houses owned by the king in 1086 there were some inherited not from King Edward, but from the Godwins, now undifferentiated in Domesday Book. We might also wonder whether the eight houses given to Battle Abbey and the five attached to Tawstock were adjacent? A group of thirteen properties could make a viable part of a "Godwin quarter" in Irlesbery. Given the association of Gytha with St Olave's church (below) and her presence in Exeter during the Norman siege of $1068,{ }^{21}$ it seems likely that all or part of the Irlesbery property was included in her dower after the death of her husband, Earl Godwin, in 1053.

Comment on St Olave's church started with O.J. Reichel who argued (a) it was founded by King Cnut - for which there is no direct evidence - and (b) it was later endowed by Gytha, Earl Godwin's wife, after the earl's death (1053) so that a priest could pray for his soul, an endowment for which there is surviving evidence. ${ }^{22}$ Of the two primary sources (see below) Reichel was aware of the "Gytha charter" (Sherford) but not of the "King Edward charter" (Kenbury). But he deduced that St Olave's had held Kenbury before 1066 because by 1086 it was held by Battle Abbey, to which St Olave's and its possessions had been given by King William.

The history of St Olave's has been discussed in the wider context of Exeter's churches by Nicholas Orme, who suggests (and it is also this author's view) that the two "pre-conquest charters"-which survive (in Latin) in the 14thcentury cartulary of St Nicholas Priory — contain reliable data even though, in

18 Domesday: Devon, 9:2, where Exeter was rendered Execestre; Exon Domesday, fols. 196a, 505b, in Libri Censualis, vocati Domesday Book, Additamenta ex Codic. Antiquiss. Exon Domesday; Inquisitio Eliensis; Liber Winton; Boldon Book, ed. H. Ellis (London, 1816), at pp. 178, 469; where Exeter was rendered Essecestra and Exonia.

19 Eleanor Searle, ed., The Chronicle of Battle Abbey (Oxford, 1980), p. 82, n.1; Domesday: Devon, 9:2.

20 Domesday: Devon, 1:40.

21 Higham, "William the Conqueror's Siege of Exeter."

22 Oswald J. Reichel, "The Domesday Churches of Devon," Transactions of the Devonshire Association 30 (1898), 258-315, at pp. 288-89; Oswald J. Reichel, "The Early History of the Principal Manors in Exminster Hundred," Transactions of the Devonshire Association, 47 (1915), 209-47, at pp. 212-13. 
surviving form, they are late concoctions, perhaps based on actual charters, on a list of charters or on a prose narrative of grants. ${ }^{23}$ The two relevant texts are: a) BL, MS Cotton Vitellius D. ix, fos. $39 \mathrm{r}-\mathrm{v}:{ }^{24}$ a grant, with a dating clause for 1063, by King Edward the Confessor of two pieces of land (a half virgate and a quarter virgate) at Kenbury (in Exminster), as well as land at Lan [an incomplete place-name], made at the request of a priest named Scepio, to "Saints Mary, Thomas the Apostle, and Olave." No witness-list or boundary clause is given. Orme suggests that Scepio is a later mis-reading, by a Latin-educated clerk who knew no Old English, of the name Sæwin (the priest who occurs also in the other charter) taken from an earlier source in Old English. ${ }^{25}$

b) BL, MS Cotton Vitellius D. ix, fo. $167 \mathrm{v}:{ }^{26}$ a grant of $1057 \times 1065$ (by reference to the witnesses) by Gytha, widow of Godwin, earl of Wessex, of land at Sherford (in the South Hams) to "the church of St Olave, king and martyr" for her soul and Godwin's soul. Witnessed by her sons, Tostig and Gyrth, earls, as well as by Sæwin the priest and "many others" unnamed; confirmed by Bishop Leofric. No boundary clause is given.

While unconvincing as late Anglo-Saxon charters-in Latin, lacking boundary clauses and with no (or fragmentary) witness-lists - their survival only in a later cartulary is insufficient reason to reject their content. There are other charters with no surviving boundary clauses and, in later copying, sometimes witness-lists (which may by then have seemed less significant) were omitted. What was important, when these two entries were written in the priory's cartulary, was the evidence they provided of the origin of endowments associated with the highest ranks: a king and the widow of an earl. Maintaining this record was part of the priory's creation of a sense of its own history: an important function of the writing of cartularies. Further, seeking an association with King Edward is understandable. Seeking association with the long-out-of-favour Godwin family can only mean this had been real: it would not have been invented at this late date. It is suggested by Nicholas Orme (personal communication) that, since the chroniclers of Battle Abbey knew that St Olave's had possessed Sherford and Kenbury, ${ }^{27}$ the original documents which underlie the

23 Orme, Churches of Medieval Exeter, pp. 150-53. The British Library MS containing the cartulary is available as a microfilm $\left(\mathrm{MFC}_{7}\right)$ at the Devon Heritage Centre, Exeter (formerly, Devon Record Office). S 1037; J.M. Kemble, ed., Codex Diplomaticus Aevi Saxonici, 6 vols (London, 1839-48), no. 814 .

25 Orme, Churches of Medieval Exeter, p. 150.

26 S 1236; Kemble, Cod. Dip., no. 926.

27 Searle, ed., The Chronicle of Battle Abbey, pp. 80-83; Sireford, Chenebury. 
cartulary entries may have been at Battle in the mid-12th century when the chronicle was written. This fascinating idea, if correct, means that the mother house had earlier collected muniments relating to its distant possessions. That the two sources occur in different parts of the cartulary suggests they came to light, during its compilation, at different times.

Confirmatory data comes from sources earlier than the cartulary: from King William's writ (in much later copies) authorizing his gifts of St Olave's and its lands to Battle Abbey; ${ }^{28}$ from Domesday Book, which places, in Battle Abbey's hands in 1086, both Sherford (part of Chillington in 1066) and a furlong in Exminster which had been leased by a (presumably royal) reeve (Eccha) before 1066 to a priest (presumably a priest associated with St Olave's church); ${ }^{29}$ from Battle Abbey's mid-12th-century "Chronicle," which narrates the grants of Sireford and Chenebury and of other gifts in Devon, including Cullompton church. ${ }^{30}$ Authenticity of the data in the cartulary is also suggested by (i) the multiple dedication of the church, which included Thomas the Apostle (a rare dedication, unlikely to be invented); by (ii) the memory of a significant player in the story, a priest called Sæwin, perhaps the same Sæwin the priest who held Swimbridge (Devon) in 1086 (in which case, a resilient survivor of the Conquest and a man who had influenced both King Edward and the Godwins);31 by (iii) the record of the (incomplete) place-name Lan: this can hardly have been invented by the cartulary's compiler and must have come from an earlier (damaged or illegible) manuscript. It does not occur in any of the other relevant sources, which suggests it came from a source independent of them.

The significance of St Olave's possession of lands for the support of priests (perhaps two, each supported by a grant) should not be overlooked. It was the only endowed church (apart from the minster/cathedral) in pre-Conquest Exeter. By 1086, only one other church had endowments: St Mary's in the castle, with its four prebendaries. ${ }^{32}$ This underlines the high status of St Olave's, with its patronage by the Godwins and King Edward, even if the church itself was small (the monks from Battle thought so, as the Battle chronicle states).

It is perhaps an open question as to whether the church was now newlyfounded, or whether-as the multiple dedication may reveal—it already

28 David Bates, Regesta Regum Anglo-Normannorum. The Acta of William I (Oxford, 1998), no. 14 .

29 Domesday: Devon, 1:34; 1:4; the furlong in Exminster is a parcel identifiable with Kenbury.

30 Searle, ed., The Chronicle of Battle Abbey, pp. 80-83.

31 Orme, Churches of Medieval Exeter, p. 150.

32 Orme, Churches of Medieval Exeter, pp. 73-80, 151, who points out that the 1086 values of their endowments were similar: St Olave's , $£_{3-2-0}$ and St Mary's, $£_{3}-15-0$. 
existed and St Olaf's name was added in conjunction with its new endowment; Nicholas Orme (below) believes all are primary dedications. Relevant to this, as well as to the church's status, is the fact that it possessed saints' relics. In the Chronicle of Battle Abbey's narrative of the foundation of St Nicholas Priory it is said that in addition to receiving gifts from King William and others, the first monks from Battle (led by Cono and Robert, successors of Gunter) raised money for their new building enterprise (which they had to initiate twice, as their first new building was burned down) by preaching sermons while travelling with "the relics for which the place is noted." ${ }^{33}$ Since the newly-arrived monks could hardly in such a short space of time have acquired new relics, these were presumably inherited from St Olave's church. The church thus seems to have had pretensions to some grandeur. Nicholas Orme has suggested these relics may have related to the three saints found in the church's dedication. ${ }^{34} \mathrm{Al}-$ though the inclusion of Mary in the dedication does not necessarily reflect ownership of a relic (though the standing which the Godwins achieved through the marriage to Gytha-who was connected to the Danish royal houseshould not rule out the possibility of their ownership of such an item), a relic of St Thomas may have been obtained by Tostig (mentioned in the "Gytha charter" and who went to Rome in 1061) or by Harold, who was perhaps in Rome in $1056 .{ }^{35}$ Since Tostig took over St Olave's church in York (see below) from Earl Siward after 1055 and, since Gytha's Danish connections were ongoing, it is not impossible that the family had acquired a relic of St Olaf himself.

Commemoration of St Olaf appears in liturgical books of Leofric, bishop of Exeter $105^{0}-72$, given by him to his cathedral. ${ }^{36}$ The tradition was still alive here in the 14th century. ${ }^{37}$ Whether this reflected the existence of St Olave's church in Exeter, or simply the wider popularity of the cult, is unclear. His feast occurs also in cathedral calendars at London, Norwich, York and Winchester and in monastic ones at Ramsey, Sherborne, Abbotsbury, Launceston and Syon. ${ }^{38}$

33 Searle, ed., The Chronicle of Battle Abbey, pp. 80-83, 258-59.

34 Orme, Churches of Medieval Exeter, pp. 150-53.

35 Barlow, Godwins, pp. 81-82, 88.

36 E.S. Dewick and W.H. Frere, eds., The Leofric Collectar (Harl. Ms. 2961) with an Appendix Containing a Litany and Prayers from Harl. MS 863, HBS 45, 56, 2 vols (London, 1914-21), 1:210-14; 2:614.

37 Dickins, "Cult of St Olave," pp. 56-57.

38 Dickins, "Cult of St Olave," p. 79; Farmer, The Oxford Dictionary of Saints p. 301. 


\section{Discussion: Exeter}

The north-west quarter of Exeter thus had a church, dedicated to the biblical saints Mary and Thomas and to the Norwegian king and saint Olaf, which was endowed with lands in Devon by King Edward the Confessor and Gytha, widow of Godwin, earl of Wessex, and also with some houses in the city. In origin, this was a private church. Its endowment with land may mean its patrons were attempting to turn it into a small minster. But since its dedication was also to St Thomas and Mary it may be that Gytha was re-founding an existing church. Whether any putative earlier (that is, pre-St Olaf) church was associated with an earlier high status residence belonging to the south-western ealdormen is an interesting (but unanswerable) question. Given the dedication to St Olaf and its endowment by Gytha, however, it is hard to escape the conclusion that it was the Godwins, earls of Wessex, who were later remembered in the name of Irlesbery (see pp. 467-68). Also testimony to the strength of local memory of the Godwins is a marginal note in a 12th-century Martyrology in Exeter Cathedral's library. ${ }^{39}$ This records the momentous events of 1066 largely in terms of the Godwin family - King Harold Godwinson and his brother Tostig — and of King Harold (Hardrada) of Norway.

Godwin himself had been projected by King Cnut, from obscure origins as a Sussex thegn, to the earldom of Wessex. ${ }^{40} \mathrm{He}$ is the best-known example of the 'new men' raised by Cnut, alongside removal or dispossession of the 1othcentury upper class. Indeed, it has been suggested that the short history of this new ruling class raised by Cnut contributed to their relatively easy suppression by William the Conqueror. ${ }^{41}$ By the 106os, the Godwin family held lands in thirty-two English shires, often holding more than twice as much land in these shires than the other great families. After the Norman Conquest, a comparably wealthy (non-royal) position in Devon was enjoyed only by the family of Baldwin de Meules, royal sheriff and castellan of Exeter. ${ }^{42}$ Domesday Book reveals that, in 1086, the sheriff received one third of the royal income of Exeter, an arrangement also found at Shrewsbury. ${ }^{43}$ Generally, however, Domesday describes this third as received by an earl, ${ }^{44}$ presumably reflecting continuity of pre-Conquest practice, a practice which had presumably applied at Exeter.

39 Exeter Dean \& Chapter MS 3518, fol.53v; also David Lepine and Nicholas Orme, Death and Memory in Medieval Exeter (Exeter, 2003), pp. 256-57.

40 For background, see Barlow, Godwins; Mason, House of Godwine.

41 Robin Fleming, Kings and Lords in Conquest England (Cambridge, 1991), pp. 48-49.

42 Fleming, Kings and Lords in Conquest England, pp. 221-22, maps 7.1, 7.2.

43 Domesday: Devon, C2; C12.

44 Domesday: Devon, C2 notes; Baxter, Earls of Mercia, pp. 100-01. 
The Godwin family were major land-owners in the south west and their greatest holdings were in Devon, Wiltshire, Hampshire, Kent, Sussex, Essex and Norfolk..$^{45}$ At the national level (to judge from Domesday Book) as earl of Wessex, Harold Godwinson was the richest man in England after King Edward. ${ }^{46}$ In addition to income from land, the late Saxon earls had the third penny from each hundred and borough court in every shire in their earldom. ${ }^{47}$ Harold's mother, Gytha, was also immensely rich, both during her marriage to Godwin and her widowhood. ${ }^{48}$ Gytha's offer, recorded by William of Poitiers, of the weight of King Harold's body in gold in return for possession of his body after his death at Hastings, was probably backed up by an ability to produce this enormous amount of gold..$^{49}$

The family certainly had interests in Exeter itself. Domesday reveals that Edward the Confessor had apportioned two-thirds of the royal revenue from Exeter to his queen, Edith, the daughter of Earl Godwin and Gytha. ${ }^{50}$ Thus, if the earl had one third and the queen had two thirds, all the city's royal revenues went to the family. There was a later, and probably reliable, tradition that Gytha, Godwin's widow, was living in Exeter when the city was besieged by William the Conqueror in 1068. This, too, strengthens the case for a significant Godwin presence in the city, the context for the property, later remembered as Irlesbery, adjacent to St Olave's church. Harold Godwinson's north Devon manor of Tawstock had five Exeter houses attached to it (possibly, though not certainly, adjacent to Irlesbery). ${ }^{51}$ Other Exeter houses, formerly belonging to the family, may have been subsumed in the total held by the king in 1086. Queen Edith held the important manor of Wonford, immediately adjacent to the city; Earl Harold acquired Exeter's port of Topsham (and see below); Leofwine, brother of Harold and Edith, held the manor of Pinhoe, also close by. ${ }^{52}$

The family saw the south west as an important part of their power base in times of political crisis. In 1052, Harold and Leofwine, the sons of Godwin, returned here (having landed at Porlock, in Somerset) from their exile base in

45 Fleming, Kings and Lords in Conquest England, pp. 57, 59, table 3.1.

46 Peter A. Clarke, The English Nobility under Edward the Confessor (Oxford, 1994), pp. 24-25, 164-91; Mason, The House of Godwine, pp. 52-53.

47 Clarke, The English Nobility under Edward the Confessor, p. 19.

48 Ann Williams, "Land and Power in the Eleventh Century: The Estates of Harold Godwinson," ANS 3 (1981), 171-87.

49 WP, II.25, pp. 140-41.

50 Domesday: Devon, $\mathrm{C} 2$.

51 Domesday: Devon, 1:40; see Higham, "William the Conqueror's Siege of Exeter" for details.

$5^{2}$ Thorn and Thorn, eds., Domesday Book: Devon. 1.28, 1.44, 1.52. 
Dublin. In 1069, the sons of Harold staged a comeback to the south west, again from Dublin, attacking the north Devon and south Devon coasts. ${ }^{53}$ Given the eminence of Exeter described in Domesday Book, where the city is ranked with London, York and Winchester, it must have been the most prestigious place in the south-western sphere of influence of the Godwins. It was not simply the shire town of Devon: it was also a sort of provincial capital. ${ }^{54}$ Around AD 1000 the Exeter mint had been amongst England's most prolific (production had declined somewhat before 1066). It had negotiated good terms about taxation and military service with 1oth- and 11th-century kings, which indicates some considerable degree of communal organisation. It defended this status-rather than a wider sense of English nationalism—against William the Conqueror in $1068 .{ }^{55}$ It has been noted that the many landed endowments of the Godwins in the reigns of Cnut and Edward were intended not simply to enrich them but also to cater for strategic needs: their lands in Essex and in the southern coastal shires gave them a base for defensive responsibilities in the Thames estuary and the English Channel..$^{56}$ Harold Godwinson's holdings in Herefordshire may reflect direct interest in defence against the Welsh. In the context of the Godwins' south-western properties, the city of Exeter, a defensible burh since the time of King Alfred situated at the head of the Exe estuary, may have had particular significance: another reason for them to develop a major presence here.

The same may be true of Harold's acquisition (as earl of Wessex) of Exeter's estuarine port at Topsham. The manor where this port was situated had belonged to St Peter's minster/cathedral in the city, who held that it had been granted by King Æthelstan. Harold somehow acquired it, a situation which led to ill-feeling between the Godwins and Leofric (the bishop, since 1050). If the rebellion of Exeter in the winter of 1067-68 was stimulated by the ambitions of the Godwin family - a possibility supported both by Gytha's presence in the city and the efforts of her grandsons to stage a comeback in the region - then it would not be surprising if Bishop Leofric lent his weight to the "peace party" which attempted to make a settlement with King William in advance of the

53 Benjamin Hudson, "The Family of Harold Godwinson and the Irish Sea Province," Journal of the Royal Society of Antiquaries of Ireland 109 (1979), 92-110; Barlow, The Godwins, pp. 62-63; Mason, The House of Godwine, pp. 194-95; Higham, "William the Conqueror's Siege of Exeter."

54 Higham, Making Anglo-Saxon Devon, pp. 167-74.

55 Higham, "William the Conqueror's Siege of Exeter."

56 Fleming, Kings and Lords in Conquest England, pp. 90-104. 
latter's siege of the city. ${ }^{57}$ Harold and his brothers acquired church property in many shires, by agreement, by the king's intervention or by their own bullying, habits they had inherited from their father, Godwin. ${ }^{58}$ In the case of Topsham, Harold's motive may have been the security of the Exe estuary or it may have been to support the activity of Scandinavian-derived merchants who probably flourished in the city (see below). Both possibilities have a long historiography. In discussing alleged spoliations of the English church by Godwin and Harold, Freeman noted the defensive possibility. ${ }^{59}$ Davidson was dismissive of this idea (Exmouth would have been more relevant) and thought controlling the commerce and port income of Topsham was Harold's motive. ${ }^{60}$ Domesday Book noted that Harold had held Topsham in 1066 and that the king held it in $1086 .{ }^{61}$ But the cathedral claimed Leofric had restored the manor to St Peter's: it is in the list of his benefactions to the minster (written in old English, originally drawn up before his death in 1072 and later copied into the Exeter Book of poetry and a Latin gospel book). ${ }^{62}$ But Domesday shows this had not been achieved by 1086, and the Topsham entry in Leofric's list—stating that Harold had taken Topsham unjustly — was interpolated between already-written lines. Nevertheless, to prepare the case, Leofric created a "Topsham charter" of King Æthelstan, together with other charters he needed to demonstrate title to estates which the church had lost (the list of his benefactions says he recovered alienated estates not only by payment, but also by advocacy - i.e. the legal process in which having charters as evidence would be crucial). ${ }^{63}$

Exeter was also the location of the shire court of Devon. With King Cnut's re-organisation of earldoms into large units with many shires, these courtsformerly presided over by the ealdormen - were presided over by the earls. In order for the earls to be present at each court, the courts must have assembled at different times. But it is possible that, to ease this complication, several

57 For a fuller discussion, see Higham, “William the Conqueror's Siege of Exeter”; Freeman's notion that the Godwins supported the Lotharingian-educated bishops, such as Leofric, to counter the king's promotion of Norman churchmen, is no longer credited: see $V E d R$, p. 109, n. 6; Simon Keynes, "Giso, Bishop of Wells (1061-1088)," ANS 19 (1996), 203-71, at pp. 212-13.

58 Fleming, Kings and Lords in Conquest England, p. 83.

59 Edward A. Freeman, The History of the Norman Conquest of England, Vol. 2 (Oxford, 1868), p. 549 .

6o James B. Davidson, "On the Early History of Dawlish," Transactions of the Devonshire Association 13 (1881), 106-30.

61 Domesday: Devon, 1:44.

62 Raymond W. Chambers et al., eds., The Exeter Book of English Poetry. A Facsimile (London, 1933).

$63 \quad \mathrm{~S} 433$. 
courts were held in the larger provincial centres ${ }^{64}$ and, if this was so, Exeter would have been the obvious place for the south-western shires. Since King Edgar's time, the shire courts met twice a year. Only one specific record of the shire court of Devon survives, preserved in the charters of Sherborne Abbey, an account of a land dispute heard at the court in Exeter, in 1045 or 1046, with Earl Godwin presiding. ${ }^{65}$ We do not know specifically where shire courts met in the shire towns by this date. Since they were held, ultimately, in the king's name, they may have been held in a royal urban property if there was a suitable one. In Exeter, evidence is emerging that such a place may indeed underlie the Norman (Rougemont) castle. ${ }^{66}$ Equally possible, however, was provision of a suitable court site within the urban properties of the earls themselves. It is perhaps in this context that significant motive may be found for the development of a comital residence, eventually with its own church, in Exeter in the decades when the Godwins were earls of Wessex-an enormous earldom stretching across southern England within which Exeter would have made an ideal centre for the south west.

The example of Chester (below) illustrates, however, that a church of St Olaf might serve not a high-status residence but a local community of Scandinavian-derived population. At Chester, this is easily understood: the city lay in the Danelaw, had a hinterland in which there had been permanent Norse settlement and was connected via the (then navigable) river Dee to the Irish Sea and the Hiberno-Norse world centred on Dublin. Exeter, in contrast, lay distant from the Danelaw. Although 'viking' influence may be seen on some of the stone carving in south west England, there is little evidence for rural settlement from immigrants. ${ }^{67}$ On the other hand, as we have seen, the Godwins had Dublin connections and, in both the internal crisis of $105^{1-52}$ and the external crisis of the Norman Conquest, the family made use of the Dublin-Devon sea route in their political reactions. It has been shown that, although an ethnic Scandinavian presence in non-Danelaw England was thin, Scandinavian personal names occur in some numbers, both in pre-Norman sources and (as a social legacy) in later sources. These names reflect partly Scandinavians who found service in England under King Cnut, and partly an adoption of Scandinavian names by English people in this period. The 11th- and 12th- century data from south-west England (Domesday Book, moneyers' names on coins, and

64 Barlow, The Godwins, p. 86.

65 Mary A. O'Donovan, ed., Charters of Sherborne, Anglo-Saxon Charters 2 (Oxford, 1988), pp. 59-61.

66 Stuart R. Blaylock and Robert A. Higham, Recent Research at Exeter Castle, Devon (in preparation).

67 Derek Gore, The Vikings and the West Country (Exeter, 2015). 
Old English written sources of pre- and post-Conquest date) suggest that Scandinavian personal names were used by people of some status: moneyers, guild members and people involved in property transactions. ${ }^{68}$ A study of the moneyers operating in Exeter itself in the reigns of King Cnut and his sons shows that, while outnumbered by English moneyers, the proportion of Scandinavian moneyers was higher (six out of a total of about twenty) than at other southern mints of the period. ${ }^{69}$

While caution is required in interpreting this data in broader terms, it may support the contention that Exeter had a small, but identifiable community of Scandinavian or, at least, of Scandinavian-derived people in the late preNorman period. Current research on Exeter's 12th-century property deeds and other local sources also reveals that a continuing minority of Exeter's influential citizens bore Scandinavian-derived names in the Norman period. ${ }^{70}$ Thus, the dedication of a church to St Olaf in Exeter might reflect not just this saint's general popularity, nor just the presence of a residence belonging to the Godwin family but also the presence of a commercially-based group with Scandinavian origins or connections. In the description of Exeter at the time of William the Conqueror's siege in 1068, penned by Orderic Vitalis in the early 12th century (from the testimony of William of Poitiers, writing around 1070), the presence of foreign merchants in the city was noted and Exeter's links with Ireland and Brittany were emphasised. ${ }^{71}$ While the locations of Exeter's Irlesbery and St Olave's church might have been influenced by the defensibility of the north-western angle of the city walls, which overlook a steep drop, they may also have been influenced by the proximity of this end of the city to the river Exe (though, it should be said, the south-western part of the city would have been even more convenient in this particular respect). The notion of a Scandinavian-derived group in Exeter, now supported by the analyses described above, goes back to the late 19th century, when it was proposed, simply on the basis of the St Olave church dedication in Fore St, in a study which strove (misguidedly) to identify several ethnic zones in the city. ${ }^{72}$ Although its

68 John Insley, "Some Scandinavian Personal Names from South West England," Namn och Bygd 70 (1982), 77-93; John Insley, "Some Scandinavian Personal Names from South West England from Post-Conquest Records," Studia Anthroponymica Scandinavica 3 (1983), 23-39.

69 Veronica J. Smart, "Moneyers of the Late Anglo-Saxon Coinage: The Danish Dynasty 10171042," ASE 16 (1987), 233-308, at pp. 301-02.

70 Julia Crick, pers. comm.

71 OV 2:210-14. Higham, "William the Conqueror's Siege of Exeter."

72 Thomas Kerslake, "The Celt and Teuton in Exeter," Archaeological Journal 30 (1873), $211-25$. 
demarcation of British and English areas does not withstand scrutiny, the idea that a Danish group - first encouraged in the time of King Cnut—lived in the Fore St area may now be seen to have some merit. ${ }^{73}$ Possibly also relevant to this putative Scandinavian community is the former chapel dedicated to St Clement, which was situated by the river Exe, north of the city, until its demolition in the sixteenth century. St Clement was popular in the Scandinavian and Scandinavia-influenced world though not necessarily first introduced into England by the vikings. ${ }^{74}$ There was another St Clement's church at Powderham, on the Exe a few miles south of Exeter, but very few in the south west as a whole. Since, however, the church immediately north of Exeter does not appear in record until around 1200 , its origins are, strictly, unknown..$^{75}$

One final dimension of the Godwin family property in Exeter is worth consideration. Nevertheless, the possibility may be borne in mind that, at least in the form in which it came to be remembered as Irlesbery, it was developed in the 1050s after the return of the Godwin family to power and influence following the political crisis of $105^{-1} 5^{2}$ during which they had been in exile. Their development of a major property in the south-western provincial capital, with its own church dedicated (inter alios) to a Scandinavian king/saint, may have been a strong signal of the family's return to power and influence in the region. It has been well said that church-building and church patronage could be powerful messages in declaring the "presence" of a major family in a particular area, and that St Olave's in Exeter may be very relevant to this theme. ${ }^{76}$ It may have been all the more significant because, in 1050, just before the Godwins' rebellion, the local power structure in Exeter had been altered with the elevation of Exeter's minster to cathedral status and the installation of a bishop (Leofric) in the heart of the city (instead of, as previously, six miles away at Crediton). The Godwins may have felt that this major change made it all the more important for their political presence to be seen - and not simply feltwhen they returned in 1052. Since Earl Godwin died in 1053, the development may have been largely implemented by Harold, his son and successor as earl. The endowment of St Olave's by Gytha, his widow, was specifically in her late husband's memory. ${ }^{77}$ Tension between the Godwins and bishop Leofric may also have played a part in the events at Exeter in 1068, when King William besieged the city. ${ }^{78}$

73 Kerslake, "Celt and Teuton in Exeter," p. 220.

74 Crawford, Churches Dedicated to St Clement.

75 Orme, Churches of Medieval Exeter, p. 89.

76 Mason, House of Godwine, p. 84.

77 For the chronology of 1050-1053, see Barlow, Godwins, p. 341.

78 Higham, "William the Conqueror's Siege of Exeter." 


\section{Discussion: National}

Attention has been drawn to the considerable documentary evidence for property in towns belonging to the 11th-century earls or their predecessors, the ealdormen. ${ }^{79}$ Given the crucial importance of towns and earls to aspects of the governance of late Saxon England, it is hardly surprising that they had urban interests and that towns figured frequently in the narratives of political events in which they were involved. Earls had the third penny from the courts, had their own urban properties and had rural manors to which urban houses were attached. While earls had no influence in some towns for particular reasons, such as the locally-dominant role of a king, of a major church or of a sheriff, the urban interests of earls-measured through the data of Domesday Bookwere widespread, occurring in almost sixty towns. Sometimes, hagae belonging to comital families are revealed in late Saxon charters (as at Worcester) or in later deeds (as at Cambridge). At Nottingham, a territory absorbed in the extended Norman city had belonged to the earls. Sometimes specific residences emerge from documentary sources, as at Exeter (see pp. 467-68), at York (see below) and Oxford (its exact location remains disputed). Sometimes churches were involved, as at Oxford, Dover, York and Exeter. At Lincoln, the earl's residence stood near a church, which was later succeeded by the cathedral, in the upper part of the city. Stephen Baxter's overview of comital urban interests shows the Godwin family had urban houses (attached to rural manors) in towns spread across the shires of their West Saxon earldom: Rochester, Romney (Kent); Lewes, Chichester, Steyning (Sussex); Guildford, Southwark (Surrey); Winchester, Cricklade, Malmesbury, Wilton (Wiltshire); Langport (Somerset); Barnstaple, Exeter (Devon). ${ }^{80}$ Variations lying behind this published summary of data are revealing. In most cases, these urban houses occurred in modest numbers. But at Steyning, by 1066 Harold had taken the whole town and church from the Abbot of Fecamp; and at Lewes, Godwin had shared the lordship of the town with Edward the Confessor. At both places, as well as at Dover (which figures prominently in the political narratives of the period, and where Godwin probably re-founded the church), we might expect the family to have possessed a residence of their own. The case of Southwark, where Godwin also had a major interest, is particularly relevant to the present discussion because it had a church dedicated to St Olaf (see below). In another discussion of urban property-holding by rural elites, it has been noted that the

79 Baxter, Earls of Mercia, pp. 97-104, for what follows.

8o Baxter, Earls of Mercia, pp. 100-01, Table 3.4. 
Godwins had some tenements in a total of 37 boroughs, ${ }^{81}$ some of which lay well outside their Wessex earldom.

A notable example of comital urban residence connected to church foundation-known because the documentary evidence and topographical data can be integrated - is at York. Here, the post-viking Northumbrian earls built an enclosed residence with church outside the city wall, at Galmanho. ${ }^{82}$ Documentary and topographical data permit reconstruction of this urban component of a comital property. ${ }^{83}$ After the conquest of Viking York in 954, the north was governed on behalf of the English kings by earls based in York. Siward, earl 1041-1055, was a Dane who came to England with King Cnut. Earl Siward supported king Edward against the Godwin family in the political crisis of $1051^{-} 52$. He was succeeded as earl by Tostig, Godwin's son, who was forced out in 1065 following a northern rebellion. Relating that event, the 12th-century writer John of Worcester noted Tostig's chamber and treasury in York. ${ }^{84}$ In its 1055 entry The D version of the Anglo-Saxon Chronicle recorded that "in this year passed away Earl Siward in York, and he lies at Galmanho in the minster which he himself had built and consecrated in the name of God and Olaf." The Life of King Edward provided the same data; the $\mathrm{C}$ manuscript of the Chronicle gave the same again but without the detail of St Olaf. ${ }^{85}$

St Olave's church (now a 15th-century rebuilding, later altered) stands just outside the north-west city wall, between Bootham Bar and the River Ouse. St Mary's Abbey was founded here in 1085, its precinct comprising a large subrectangle, in which the church was incorporated by the precinct entrance. The first precinct seems to have been surrounded by the earlier comital enclosure, since the monks were led to settle here "on account of the security/defence of the place (propter loci munitionem)." An early name for Bootham Bar was Galmanlith, related to Galmanho. Later, the area around the Abbey was known as "Earlsborough." This led to the long-held interpretation that the earls had a residence here adjacent to St Olaf's, that the boundary of their property was reflected in the later abbey precinct, and that the abbey entrance (later St Marygate) coincides with the entrance to the earlier comital enclosure (the

\footnotetext{
81 Fleming, "Rural Elites and Urban Communities," pp. 7-8.

82 David M. Palliser, Medieval York 6oo-1540 (Oxford, 2014), pp. 64-65, for the site's context in York's history; Peter V. Addyman, The British Historical Towns Atlas. Volume 5: York (York, 2015); Dickins, "Cult of St Olave," pp. 56-57.

83 For what follows, see VCH Yorks, 3, pp. 107-08; vcH Yorks: City of York, pp. 13-17, 357-60; Royal Commission on Historical Monuments, York. Vol. 2. The Defences (London, 1972), pp. 8-9.

84 JW vol. 2, pp. 596-99.

85 ASC C 1055; VEdR, p. 31.
} 
present enclosing wall with gatehouse is 13th-century). The wider estate for which this urban property was the centre included immediately extra-mural lands and nearby rural manors. These had perhaps been taken out of earlier minster lands with the support of Kings Cnut and Edward the Confessor. The estate passed mainly to count Alan I of Brittany, and from him to a monk from Whitby for foundation of a Benedictine house. Progress was delayed by a dispute with Archbishop Thomas, settled by William the Conqueror. In 1088, William Rufus donated further adjacent property to the monks, presumably also an element of the former comital precinct, so that a new church, St Mary's Abbey, could be founded. ${ }^{86}$

There are clear parallels between Exeter and York. They have been observed as southern and northern examples of linked residence and church ${ }^{87}$ but similarities and differences in detail are significant. In both, a comital property with a church dedicated to St Olaf was given after the Conquest to a new Benedictine monastery through the intervention of a king. In both, the old church survived beside the new monastery, being too small for the new monastic community's requirements. In York, the site was immediately outside the city wall, whereas at Exeter it lay inside. York had a cultural, economic and political background of Scandinavian influence. In Exeter, such a background was limited, though a community of Scandinavia-derived people lived and worked in the city. In York, there are indications of enclosure-even defence-around the perimeter of the comital residence. In Exeter, the matter of enclosure remains unresolved. After Siward's death in 1055 and Tostig's occupation of the northern earldom, the Godwin family possessed two residences and powerbases, in the south and north of England, with remarkably similar elements.

Since churches dedicated to St Olaf were important elements of both the Northumbrian earls' residence in York and the West Saxon earls' residence in Exeter, we may wonder whether there was a connection between such churches in towns and the location of very high status secular residences. The evidence does not, however, support such a general argument, as the occurrence of St Olaf's churches in towns is too diverse. In Chester, a significant trading city and shire centre where a high status residence might be expected, there is nothing to suggest such a site, despite the city having a church dedicated to St

86 Another high status and enclosed property in the city may be identifiable in the southeast corner of the Roman fortress, where the topographical name 'Arkilltofts' derives from Arnketil, the name of a prominent rebel against William the Conqueror. S.R. Jones, York. The Making of a City 1068-1350 (Oxford, 2013), pp. 50-54, 65, 93.

87 Blair, The Church in Anglo-Saxon Society, p. 403. 
Olaf. It lies outside the city's walled area, in Lower Bridge St, but without supporting data suggestive of a linked high status residence. ${ }^{88}$ The church's origin is unknown: it first occurs in written record early in the 12th century. ${ }^{89}$ Lower Bridge St had also another church, dedicated to St Bridget. These two churches may have served a Norse-Irish community of traders living and working between the city wall and the River Dee. Since St Olaf's church cannot have originated earlier than the 1030s, it is likely that St Bridget's church, immediately outside the city's south gate, was the primary foundation of this community, and St Olaf's, further away from the city, was a secondary foundation. Domesday Book noted that Chester, like Lincoln and Stamford, was governed in Anglo-Scandinavian tradition by a group of twelve iudices or "lawmen."

\section{Chichester}

Chichester, with a St Olaf church in North Street, provides a very different, but most interesting case. Much altered in the later Middle Ages (a bookshop since 1956) the basic structure is 11th-century in origin, but commentators differ as to whether dating from just before or from just after the Norman Conquest..$^{90}$ It contains re-used facework masonry from Chichester's Roman city wall. The original door-visible as a blocking — to the small nave (measuring $25^{\prime} 6^{\prime \prime} \times$ $17^{\prime} 4^{\prime \prime}$, approximately $\left.7.75 \mathrm{~m} \times 5.25 \mathrm{~m}\right)^{91}$ was on the south, replaced in the 14th century by a western entrance on the street frontage. This sequence raises the possibility that the original door led to a private house (see below), a door to the street only being necessary in a later (parochial) context. The chancel is a 13th-century addition or replacement, out of alignment with the nave, measuring $13^{\prime} 8^{\prime \prime} \times 13^{\prime} 10^{\prime \prime}$ (approximately $4.25 \mathrm{~m}$ square). This re-building of the east end may have coincided with the acquisition of the church by Chichester cathedral. The chancel arch was rebuilt around $185^{\circ}$ (Figs 23.6, 23.7, 23.8).

A local published tradition maintains that the church was founded by Grimcytel, bishop of Selsey (the South Saxon see until 1075 when it was superseded by Chichester) from 1039 to his death in $1047 .{ }^{92}$ This idea rests on the assumption

88 J.D. Bu'lock, Pre-Conquest Cheshire, 383-1066 (Chester, 1972), pp. 59-6o, 76.

89 Dickins, "Cult of St Olave," pp. 70-71, cites a reference in 1101.

9o VCH Sussex 2, p. 365; vcH Sussex 3, pp. 162-63; Ian Nairn and Nicholas Pevsner, The Buildings of England: Sussex (Harmondsworth, 1965), p. 179.

91 Andrew Westman, Chichester City Walls (Chichester, 2012), p. 103; see the published plan in $\mathrm{VCH}$ Sussex 3, pp. 162-63.

92 For an example, see J.R. Cann, St Olaf's Church, Chichester (Chichester, n.d.). 


\section{St Olaf's, Chichester}
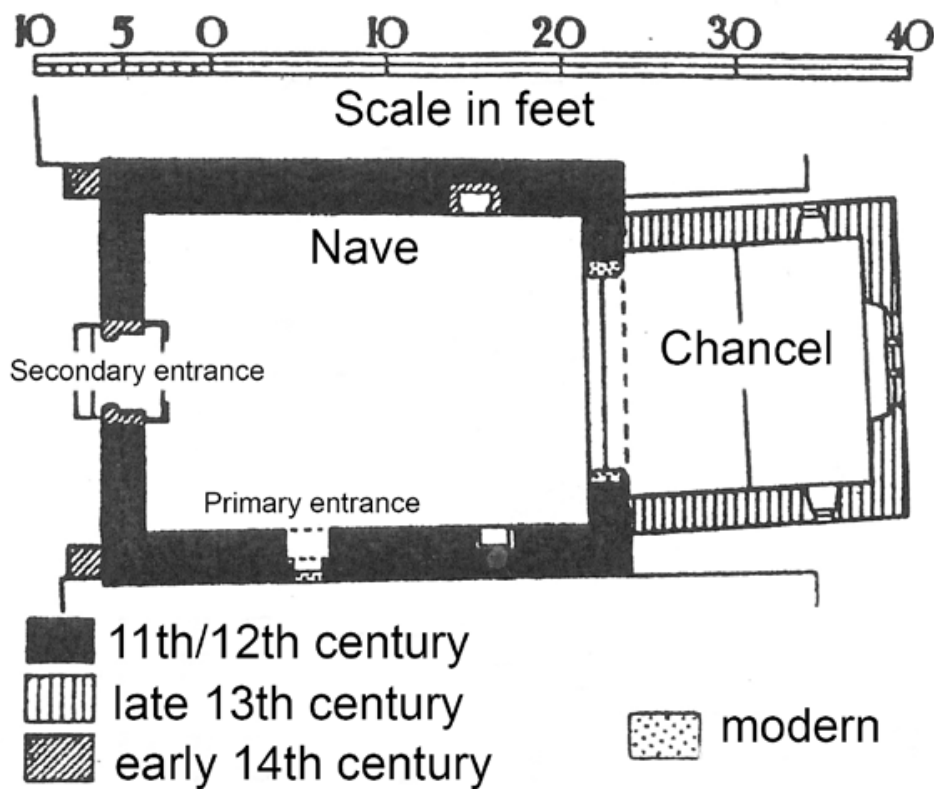

FIGURE 23.6 Plan of St Olaf's church, Chichester, showing structural phases from the 11th to 12th centuries onwards.

BASED ON VCH SUSSEX VOL. 3 (1935), P. 162, WITH ADDITIONS;

(C) UNIVERSITY OF LONDON (VICTORIA COUNTY HISTORY), WITH THANKS

that he had been in Norway and was identical with the man who appears in Scandinavia as Grimkel, one of King Olaf's Christian missionaries who was instrumental in his canonisation in $1031 .{ }^{93}$ If so, perhaps he established this small urban church, in his English diocese, in memory of his former patron. The association of Grimkel with King Olaf appeared in 13th-century sagas, but has earlier origins, starting with Adam of Bremen in the 1070s and then appearing in late 12th-century sources. ${ }^{94}$ In these accounts, Grimkel figured amongst a group of English bishops and priests serving as missionaries for King Olaf, who had taken them to Norway after a campaign fought in England on behalf of King Æthelred. If this Grimkel is to be identified with bishop Grimcytel of

93 Farmer, The Oxford Dictionary of Saints, pp. 300-01.

94 Adam of Bremen: History of the Archbishops of Hamburg-Bremen, ed. and trans. Francis J. Tschan (New York, 1959), pp. 94, 214; A History of Norway and the Passion and Miracles of the Blessed Óláfr, ed. Carl Phelpstead and Devina Kunin (London, 2001), p. 25; Theodoricus Monachus: An Account of the Ancient History of the Norwegian Kings, ed. D. McDougall and Ian McDougall (London, 1998), p. 33. 


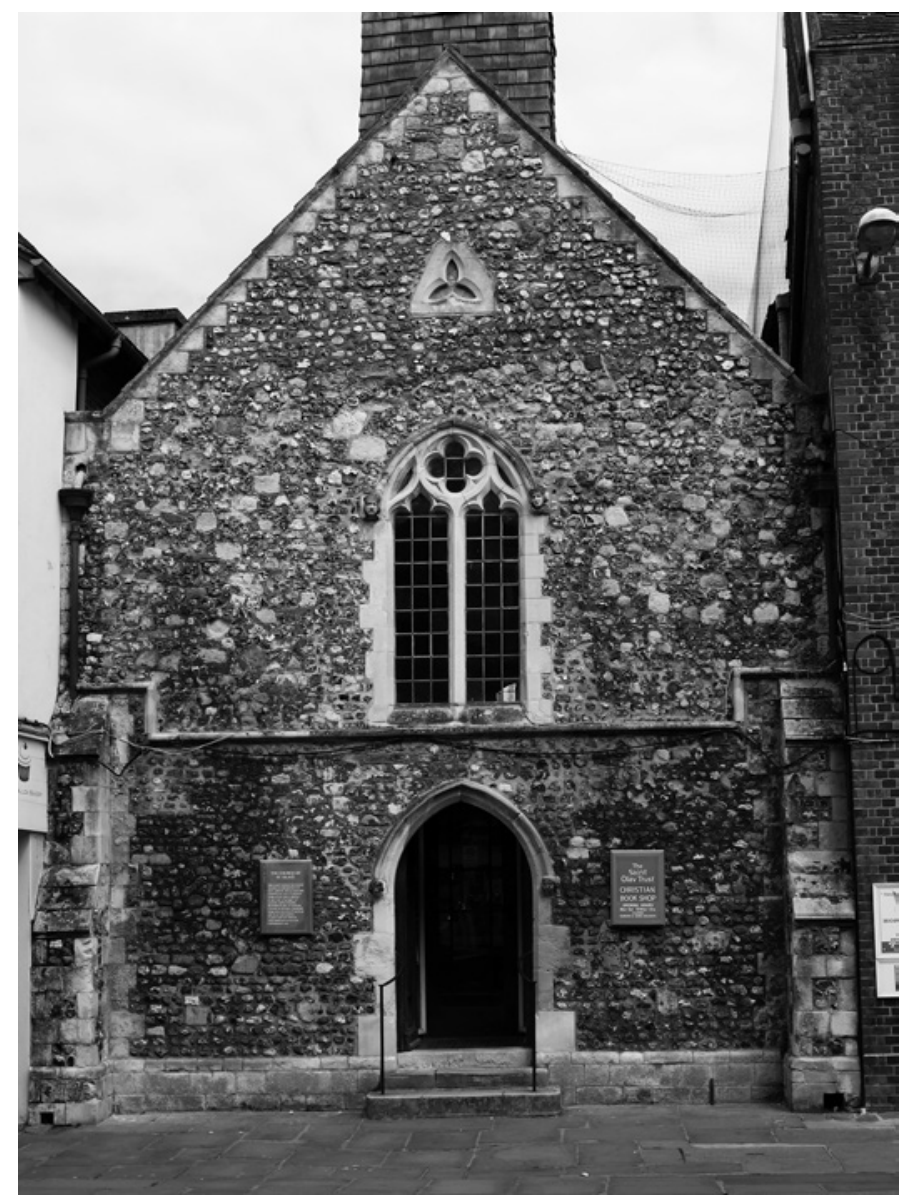

FIGURE 23.7 St Olaf's church, Chichester, from the west

(C) THE AUTHOR

Selsey, it appears, however, that he was back in Norway shortly before his own death. There, he figured in the agreement of 1046-47 between Magnus (King Olaf's son) and Harold Hardrada (Magnus's uncle) concerning the future rule of Norway and Denmark..$^{95}$ Grimcytel is said to have purchased the see of Selsey from King Harold Harefoot in 1039 and may also have purchased the see of Elmham from King Edward in 1043. ${ }^{96}$ His death in England in 1047, and his burial in Canterbury, were noted in the ' $\mathrm{C}$ ' version of the Anglo-Saxon Chronicle. It must be emphasised, however, that the identification of Grimkel with

95 Theodoricus Monachus, ed. McDougall and McDougall, p. 43.

$96 V E d R$, pp. 76, 108, 222. 


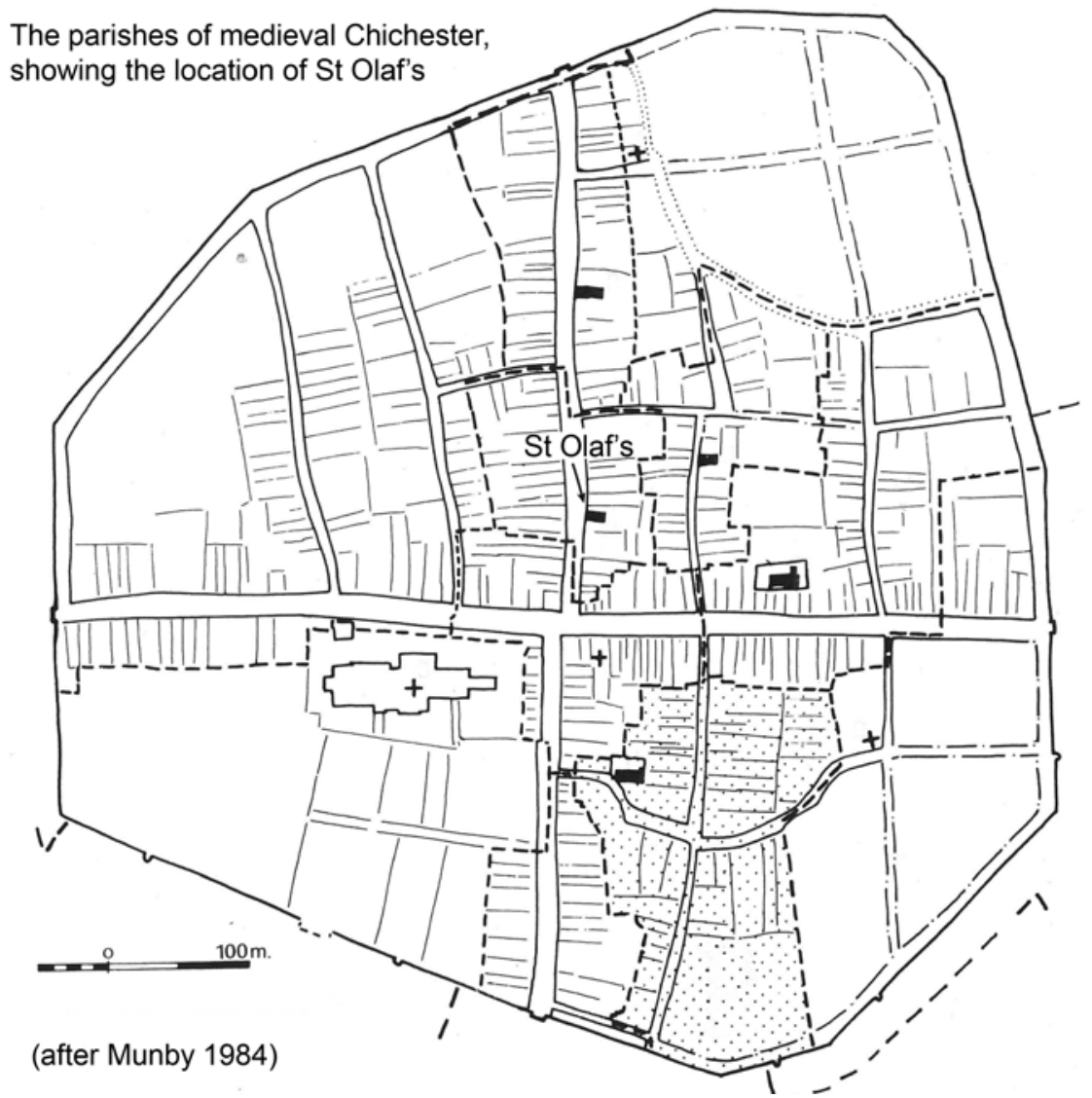

FIGURE 23.8 The medieval parishes and churches of Chichester, showing the parish of St Olaf and its church.

BASED ON MUNBy, "SAXON CHICHESTER AND its PREDECESSORS," (FIG. 108), WITH AMENDMENTS. BY PERMISSION OF ITS AUTHOR, WITH THANKS

Grimcytel has (to this author's knowledge) not been proven. Lesley Abrams has noted that Grimkel simply sounds like a Norse name, without making reference to Bishop Grimcytel, and that another of the missionaries named by Adam of Bremen was Rodulf, whose name sounds Norman. ${ }^{97}$ Olaf may have brought them from England, but the supposed English origin of this missionary group (including also Sigfrid and Bernhard, whose names look German) may be spurious. Grimkel appears as a personal name in England, mainly in

97 Lesley Abrams, "The Anglo-Saxons and the Christianization of Scandinavia," ASE 24 (1995), 213-49, at pp. 223-24. 


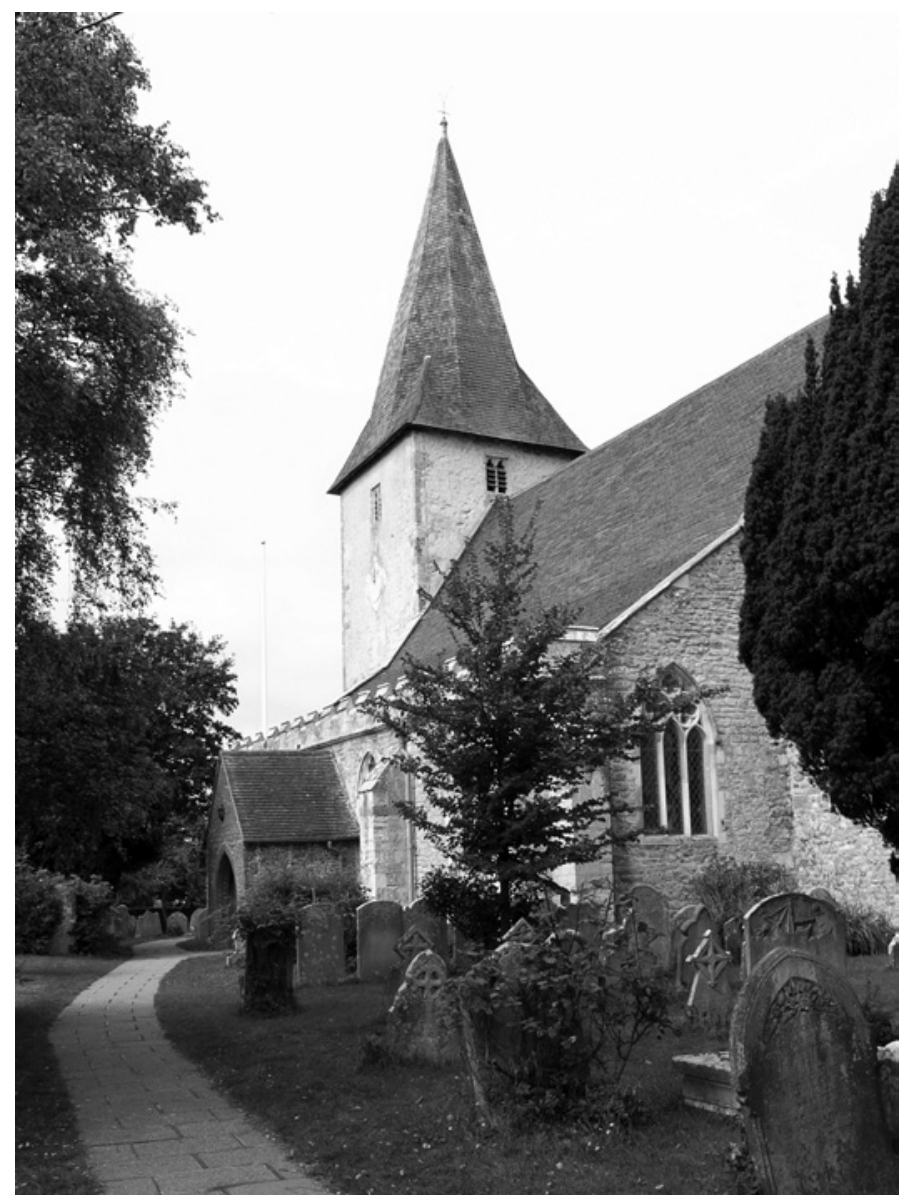

FIGURE 23.9 Bosham church, Sussex

(C) W. WOODBURN, REPRODUCED WITH THANKS

the Danelaw shires. Grimcytel occurs as a personal name in several English contexts, including for moneyers in eastern England.

There is, in any case, another possibility for the foundation of St Olave's in Chichester which deserves serious consideration, namely that the church was founded by Earl Godwin for a Scandinavian group, and that the earl may have had an associated urban residence. ${ }^{98}$ Dickins noted Scandinavian names in 11th-century Chichester. ${ }^{99}$ Further support for this suggestion might be found in Domesday Book, which reveals that several of Godwin's manors had

98 Proposed in vcH Sussex 3, pp. 83-84, 166.

99 Dickins, "Cult of St Olave," p. 68. 
possessed house properties in Chichester, clearly indicating he had a significant interest in the city: Stoughton, with fifteen; Bosham, with eleven; Singleton, with nine; Westbourne, with six; ${ }^{100}$ other manors, Chithurst, Stedham, Selham, Lavant, and Compton, had just one or two attached city properties. ${ }^{101}$ Countess Gytha, had two manors with properties in Chichester: Harting, with eleven; Marden, with one. ${ }^{102} \mathrm{~A}$ location for the Godwins' houses in Chichester has been suggested in North St and West St. ${ }^{103}$ Caution is needed, however, as Domesday Book's description of Chichester says that in 1066 there had been just under a hundred properties there, but that by 1086 there were a further sixty. ${ }^{104}$ So it is possible that the number of urban houses attached to Godwin's former manors had increased since 1066. Godwin had one third of the customary dues paid by the urban properties. ${ }^{105} \mathrm{~A}$ number of non-Godwin manors also had Chichester properties, and the rest had presumably belonged either to the King or the Church, but as much as 50 per cent of Chichester may have belonged to manors held by the Godwins. It has been noted that, "encircled by a ring of estates held by the Godwinsons and their men" Chichester was "thoroughly Godwinist."106

As well as the possibility that St Olave's in Chichester was founded for or by a Godwin-supported community, the possibility that it also had a specific connection with nearby Bosham (within five miles) should be considered (Fig. 23.9). At Bosham, there were two manors by the mid-11th century. ${ }^{107}$ One manor, including 112 hides of land and a church (the present church of Holy Trinity) had been given as a gift by Edward the Confessor to his Norman chaplain, Osbern. ${ }^{108}$ In 1072, Osbern became bishop of Exeter and in 1086 he still possessed his Bosham manor but it had been reduced in size to its (as Domesday relates) original extent of 65 hides by the loss of outlying territories. In the Anglo-Saxon and early Norman periods, the church at Bosham was a minster supported by its rich manor. In the early 12th century, Bishop William Warelwast of Exeter transformed it into a college of six secular canons, whose deans would be the bishops of Exeter. The college used the east end of the church, while the nave was used as the parish church, connected to Chichester diocese. This split in

\footnotetext{
100 Domesday: Sussex, 1:1; 11:3; 11:30; 11:37; Bosham is discussed below.

101 Domesday: Sussex, 11:5; 11:9; 11:10; 11:14; 11:36.

102 Domesday: Sussex, 11:6; 11:33.

103 vcH Sussex 3, pp. 83-84.

104 Under the holdings of Earl Roger of Montgomery; Domesday: Sussex. 11:1.

$105 £ 10$ to the king; $£_{5}$ to the earl; Domesday: Sussex. 11:1.

106 Fleming, "Rural Elites and Urban Communities," p. 13.

$107 V C H$ Sussex 4, pp. 182-88; they became a hundred in the 13th century.

108 Domesday: Sussex, 6:1.
} 
responsibility led to disputes between the bishops over many centuries. ${ }^{109}$ Further evidence for Bosham church's minster status comes from Domesday Book itself. ${ }^{110}$ Bishop Osbern's manor contained a sub-manor called Thorney, which had its own church and priest but whose tithe was owed to the priests (plural: clerici) of Osbern's own church.

The other Bosham manor had been the property of the Godwins, earls of Wessex. ${ }^{111}$ In 1086 it was held by King William, one of only two (also Rotherfield) Sussex manors retained by him: both had been Godwin's manors. At Bosham, the Godwins had ship-building interests in the harbour, where they also kept their personal fleet.112 It was at Bosham in 1049 that Swein, Godwin's son, seized his cousin, Beorn, and took him in his ships to Dartmouth, where he was infamously murdered. ${ }^{113}$ Bosham also figured in the narrative of the rebellion of the Godwins against King Edward in 1051-52. The family's manor house at Bosham occurs in a scene on the Bayeux Tapestry illustrating the start of Earl Harold's crossing of the English Channel in 1064. It is assumed that the Tapestry refers to Harold's Bosham property rather than Osbern's. The house is shown as a first-floor hall with a feast taking place. This scene also includes a church: the two crosses on its roof distinguish it from a secular building and ecclesia is written in the legend above. If this is the church mentioned in Domesday's description of the Godwins' manor, then it no longer survives. If it is present-day Bosham's church, then the Tapestry's designer transposed it from Osbern's manor for visual effect. It has long been recognised that the existence of two manors complicates interpretion of this scene on the Tapestry: logically, it should be the hall and church in the Godwins' manor which are depicted, the present-day Bosham church thus possibly being irrelevant to the issue. ${ }^{114}$ Whether any of the (named) buildings on the Tapestry looked like their depictions has long been argued about. ${ }^{115}$ In the present author's view, the depictions of the church and hall at Bosham are likely to be emblematic rather than based on specific structures. They show what sorts of buildings a manor belonging to such a wealthy family as the Godwins should contain, in a

\footnotetext{
109 VCH Sussex 2, pp. 109-12.

110 Domesday: Sussex, 6:1.

111 Domesday: Sussex. 1:1.

112 Philip MacDougall, "Bosham. A Key Anglo-Saxon Harbour," Sussex Archaeological Collections 147 (2009), 51-6o.

113 ASC CD 1049.

114 F.M. Stenton, ed., The Bayeux Tapestry, 2nd ed. (London, 1965), p. 79; D.M. Wilson, ed., The Bayeux Tapestry (London, 1985), p. 217; Mason, House of Godwine, p. 84.

115 Elisabeth C. Pastan, "Building Stories: The Representation of Architecture in the Bayeux Embroidery," ANS 33 (2011), 151-85, at pp. 162-64.
} 
place that was important in the narrative. If the designer knew there were two manors, perhaps the church from one (Osbern's) and the hall from the other (Harold's) were shown, as the finest buildings there.

Domesday Book says that the Godwins' manor of Bosham, rated at $5^{6} \frac{1 / 2}{2}$ hides, included also a church (location not specified) and eleven properties in Chichester. ${ }^{116}$ By 1086, King William had given ten of these to the bishop of Chichester. Domesday makes no mention of St Olave's church in Chichester, so we have no independent evidence of its context. But it is possible that the church listed for the manor of Bosham was situated with that manor's Chichester properties and that the Godwins founded this church to serve their own and their urban tenants' needs, tenants attached to their Bosham manor. A location for a "lost" church in Bosham has been suggested at Crede, where early O.S. maps and local property deeds mark the place as "Site of Monastery," but nothing to demonstrate the truth of this has been established. It is difficult to see how a church (substantial, if it was the one depicted on the Bayeux Tapestry) has disappeared without trace. ${ }^{117}$ Association of the Godwins with St Olave's church, Chichester, is not, however, dependent on identifying it with the church of their Bosham manor. The latter might have disappeared and the urban church may have been a separate Godwin foundation for their tenants. ${ }^{118}$ Whatever its origins, the church later had a small urban parish straddling North St. Whether this reflected an earlier and secular property unit is an interesting question. Pagham manor, which belonged to the archbishops of Canterbury as a gift of Saint Wilfrid, was said by Domesday Book to have a church in Chichester as well as one in the rural manor. ${ }^{119}$ This provides a parallel for the Bosham-St Olave's hypothesis suggested here: an early city church belonging to a rural manor. The church in question was All Saints, in south-eastern Chichester (the rural church was St Andrew's; later St Thomas the Martyr). The 12-acre urban parish was the archbishops' jurisdiction which eventually became known as The Pallants, a name derived from Palenta - the paled (enclosed) area referred to in 12th-13th-century sources-rather than, as sometimes suggested, from palatium (palace). ${ }^{120}$ It was in Aldwick Hundred, but was taken over by the city in $155^{2}$. The church, however, remained

\footnotetext{
116 Domesday: Sussex, 1:1.

117 I am grateful to Joan Langhorne, Bosham's church archivist, for all these details; for a recent illustrated history of Bosham and its famous church, see also her A Guide to Holy Trinity Church, Bosham (Bosham, 2013).

118 As suggested in vcH Sussex 3, pp. 83-84, 166.

119 Domesday: Sussex, 2:5.

120 VCH Sussex 3, pp. 103-04; VCH Sussex 4, pp. 227-33; Julian Munby, Saxon Chichester and its Predecessors (Chichester, 1984), pp. 327-28.
} 
an archbishop's peculiar after that. Domesday Book also reveals that, in 1086, several manors which had belonged to the Godwins before 1066 had churches, but whether built before or after 1066 is unclear. By 1086, these manors were held by earl Roger (of Montgomery) or his tenants. ${ }^{121}$

\section{Southwark}

Finally, the interest of the Godwin family in Southwark, at the south end of London Bridge, should be noted (Figs 23.10, 23.11, 23.12. 23.13). Southwark was developed by around 900 as a defended place opposite the city of London on the north bank of the Thames (hence the "south" element of Southwark). In the Burghal Hidage list (Surrey was in Wessex, whereas London was in Mercia) it was known as Suthringa geweorc - the southern fortification. Although a possible link between the Godwins and the St Olave's church which formerly stood in Southwark has been noted, ${ }^{122}$ this possibility seems never to have been explored. The general Godwin-Southwark connection occurs, in fact, in both in English and Norman sources. A Godwin property here figures in the narrative of the family's rebellion against King Edward in 1051-1052. London and Southwark were key places at several points in the story told in the AngloSaxon Chronicle and the "Life" of King Edward. ${ }^{123}$ The D version of the AngloSaxon Chronicle says that on his return to England in 1052, Earl Godwin had a particular alliance with the men of Southwark, established in earlier years. The Chronicle also noted local networks of men loyal to the Godwins in Dover and Bristol, perhaps because the growth of local loyalties was a natural outcome of the development of urban interests by powerful families. ${ }^{124}$ During his progress around London after the battle of Hastings, as described by William of Poitiers, Duke William's troops burned "all the houses they could find on this side of the river" - presumably Southwark — after driving London's defenders within their city wall. ${ }^{125}$ The "Life" of King Edward says Godwin had a mansio in Southwark, construed by some commentators specifically as his house, but by the modern editor simply as his manor. ${ }^{126}$

\footnotetext{
121 Domesday: Sussex, Chithurst, 11:9; Climping, 11:75; Compton, 11:36; Singleton, 11:3; Stedham, 11:10; Stoughton, 11:37.

122 Dickins, "Cult of St Olave," pp. 67-68.

$123 V \notin d R$, pp. 21, 27; Frank Barlow, Edward the Confessor (London, 1970), pp. 112-14, 123-24; Barlow, The Godwins, pp. 58-59, 64-65; Mason, House of Godwine, p. 72.

124 Fleming, "Rural Elites and Urban Communities," p. 10.

125 WP, II.28, p. 146-47.

$126 \quad V Æ d R$, p. 21.
} 


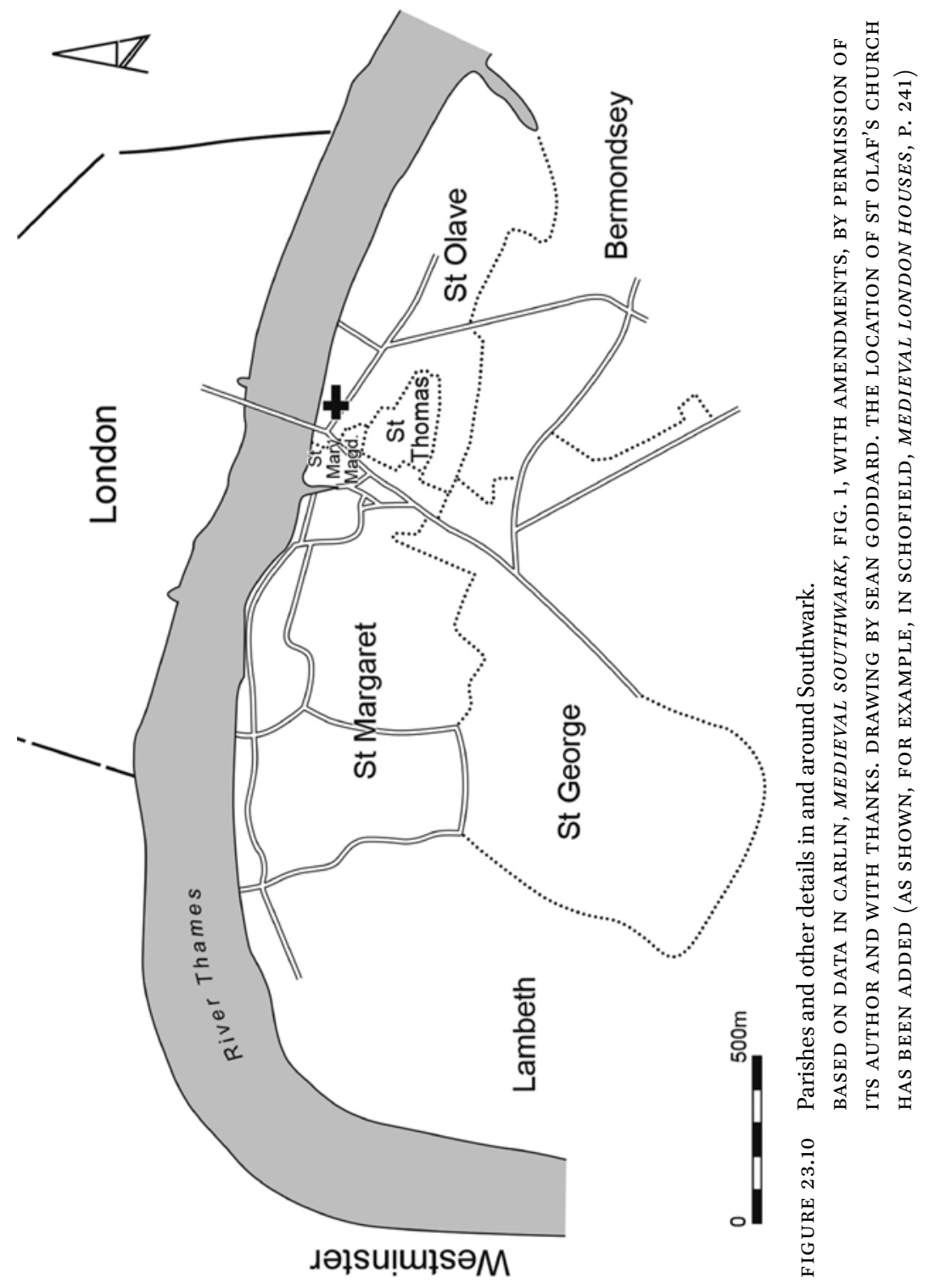




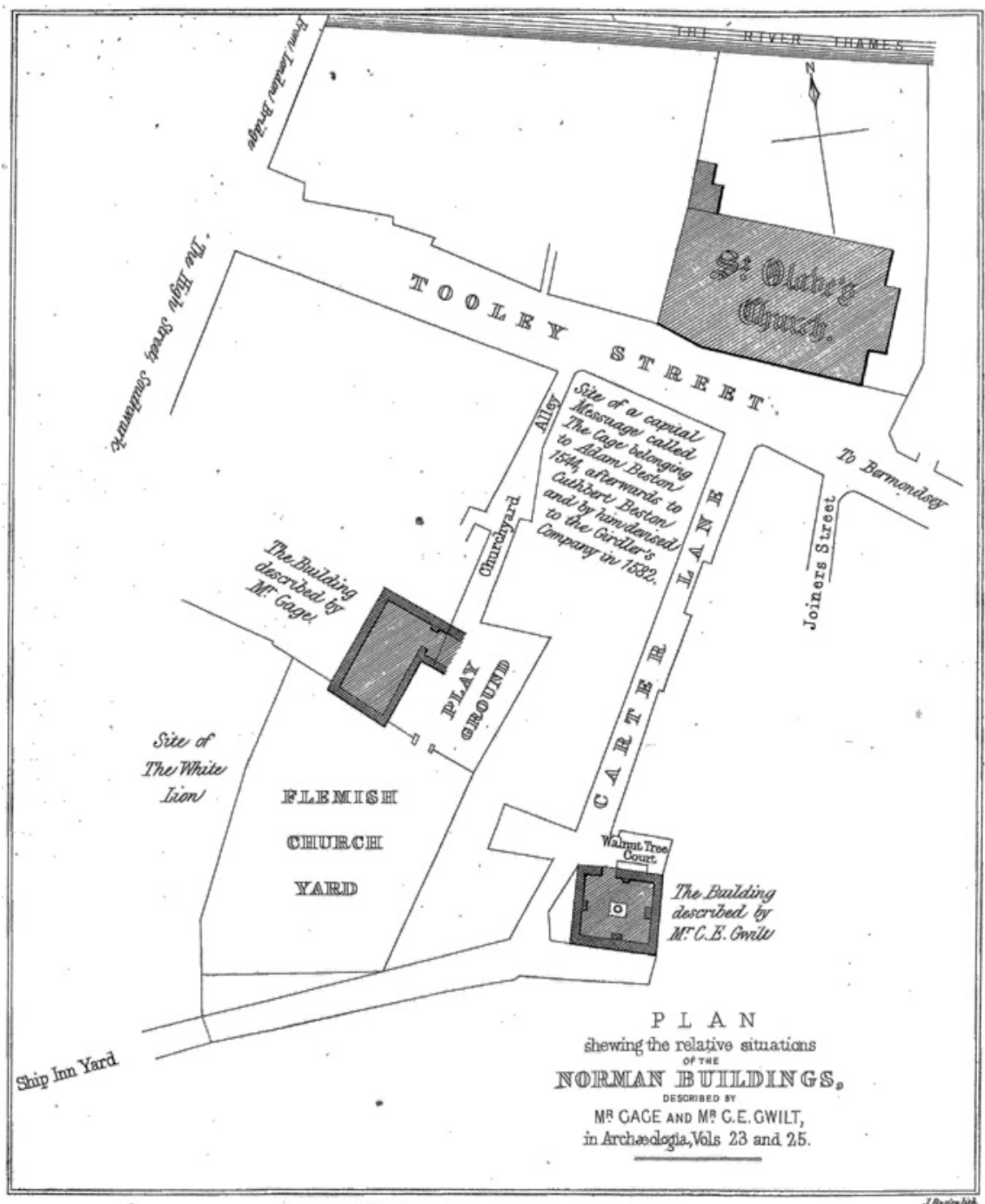

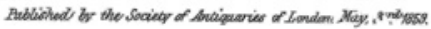

FIGURE 23.11 Locations of 12th-century houses (earls of Warenne and priors of Lewes) discovered in 1830 near St Olave's church, Southwark; illustrated (survey by J. Basire) in Corner, "Observations on the Remains of an Anglo-Norman Building," plate I

BY KIND PERMISSION OF THE SOCIETY OF ANTIQUARIES OF LONDON

Domesday Book reveals that both King Edward and the Godwin family had interests in Southwark (Sudwerche). ${ }^{127}$ The king had possessed a minster (monasterium) church and an aquae fluctum. These were, respectively, the church

127 VCH Surrey 1, p. 303; Domesday: Surrey 5:28 and note. 


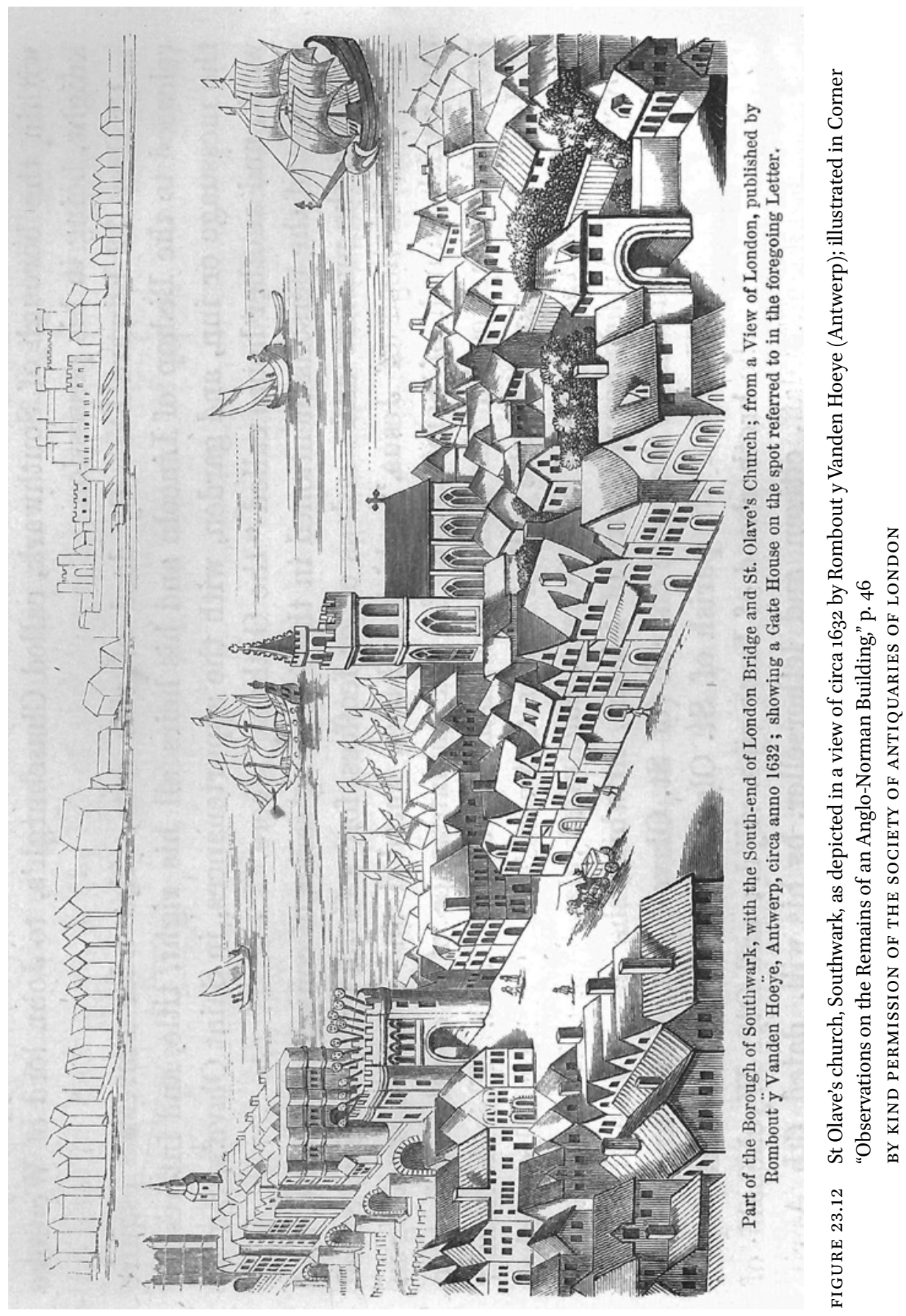




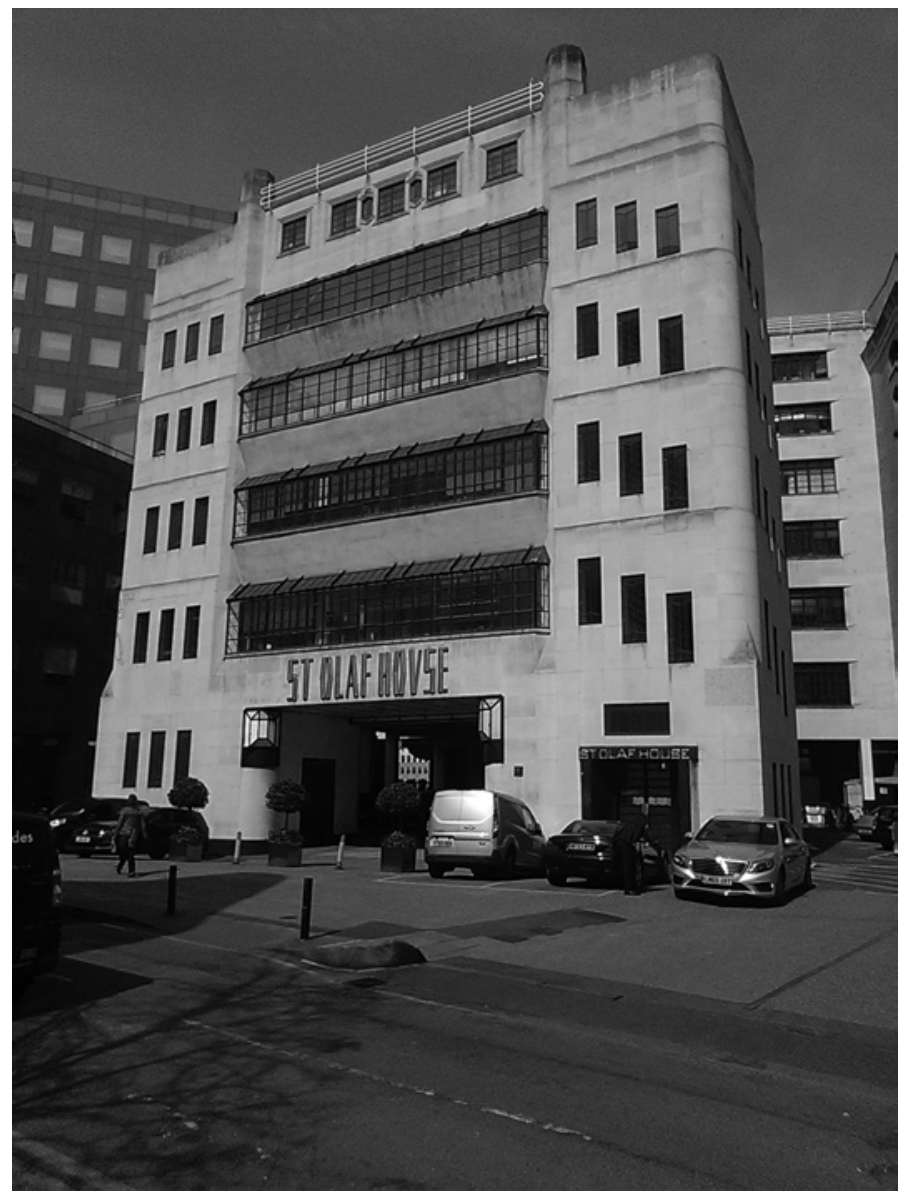

FIGURE 23.13 St Olaf House, Southwark (built in 1930s), on the site of St Olave's church (C) J. BEERE, REPRODUCED WITH THANKS

later known as St Mary's, and the nearby tidal inlet from the Thames later called St Mary's dock or St Saviour's dock. ${ }^{128}$ Both of these had by 1086 been granted by William I to Odo, bishop of Bayeux and earl of Kent, who had given them to two other men - first, Æthelwold and later, Ralph—in exchange for a house in Southwark. Domesday Book relates that tolls taken for the mooring of ships had been shared between King Edward (two thirds) and Earl Godwin (one third). It is likely that the whole area, given its role in London's security, had originally been royal demesne from which specific properties had later been granted out. The Godwins' property and commercial rights had perhaps

128 Martha Carlin, Medieval Southwark (London, 1996), pp. 15-22. 
originated in a grant from King Cnut, though none is known. It has been suggested that, since, in an on-going dispute between Bishop Odo and the king, it was said on local testimony recorded in Domesday Book, that only the king had had the river tolls along the waterfront (strande), Godwin's right to his share of the tolls may have lapsed on his death in 1053 and now been claimed by the bishop. ${ }^{129}$ If this was the case, it supports the idea that Bishop Odo had been granted the Godwins' property (see below).

The Godwins were extensive land-holders in Surrey. ${ }^{130}$ Southwark gave them a secure base, opposite London and not far from Westminster, the site of Edward the Confessor's new principal residence and royal abbey. By 1066, Harold Godwinson was in possession of Bermondsey, on the east side of Southwark, and Lambeth, to its west. In 1086, the king held Bermondsey, where Domesday Book noted the new church, presumably the Cluniac priory established in 1082. ${ }^{131}$ Harold had granted Lambeth to the canons of his own foundation at Waltham; in 1086 it was held by the count of Mortain. ${ }^{132}$ It is possible that the Godwin connection with Lambeth went back to 1046, when King Edward exiled Osgod Clapa, one of King Cnut's major supporters. According to the 12th-century writer John of Worcester, King Harthacnut collapsed at Lambeth in 1042, while attending a feast to celebrate the marriage of Gytha, the daughter of Osgod Clapa, to Tofi the Proud, a Dane. The king died soon after (8 June), and was buried at Winchester, next to Cnut, his father. ${ }^{133}$ Although it is not actually stated here that Lambeth was Osgod's manor, this seems a reasonable deduction. Perhaps Lambeth had been given to Osgod by King Cnut and was then given, by King Edward, to Godwin. The tenure of Lambeth was, however, also complicated by a second manor there, which Domesday Book says had been held by Goda, the sister of King Edward, who died in $1056 .{ }^{134}$

The Godwin family had thus developed a major presence on the south side of the Thames. Their Surrey manor of Merton (held by Harold in 1066) had sixteen houses in Southwark attached to it, and the manor of Oxted (held by Gytha in 1066) had one house in Southwark. ${ }^{135}$ This raises the question, discussed in relation to Exeter and Chichester (see above), as to whether an urban church may have been an appendage to a high status house, or also built to

\footnotetext{
129 VCH Surrey 4, p. 135.

130 VCH Surrey 1, pp. 281-82; on early Surrey churches, see also John Blair, Early Medieval Surrey: Land-Holding, Church and Settlement before 1300 (Stroud, 1991).

131 Domesday: Surrey, 1:4.

132 Domesday: Surrey, 17:1.

133 JW vol. 2, pp. 532-35.

134 Domesday: Surrey, 14:1.

135 Domesday: Surrey. 1:5, 15:1.
} 
serve its lord's urban tenants. The situation was not, however, unique to the Godwins: several other lay and ecclesiastical lords also had manors with attached houses in Southwark and/or London. ${ }^{136}$ In 1086, about fifty houses in Southwark were attached to various rural manors, but this can hardly have been the total number of houses in this important place. ${ }^{137}$ Later, Southwark was a favoured location for houses of the rich and powerful: church institutions from the 12th century, and secular gentry and nobility from the 14th century. ${ }^{138}$ Perhaps the Godwins had been early exponents of this social trend.

Tooley Street in Southwark, running east from the south end of London Bridge, takes its name from the church of St Olaf-by elision of "Saint" and "O" - which formerly stood on the north side of the street near the bridge. ${ }^{139} \mathrm{In}$ the Middle Ages the street was known as 'the royal highway' (vicus regius or regia strata) and by the 16 th century, as St Olaf's Street. ${ }^{140} \mathrm{~A}$ pre-Norman origin for St Olave's, Southwark seems highly likely: the church definitely existed in the later 11th century. The church was amongst the early gifts made-mainly in Sussex but also in Surrey-to Lewes Priory (Sussex). The grant was made probably by William de Warenne, who founded the priory with his Flemish wife, Gundreda (it was the first Cluniac priory in England) around 1077-78 out of the old minster of St Pancras. ${ }^{141}$ But since the evidence for the grant comes from 12th-century confirmations of Lewes Priory charters, it may possibly have been made by the founder's son, also William. ${ }^{142}$ Domesday Book shows that before 1066 the lordship of Lewes had been shared between King Edward and the earl of Wessex. ${ }^{143}$ In 1086, King William had the royal portion; William de Warenne (founder of Lewes Castle and Priory and, in 1088, earl of Surrey) had the Godwin portion. When the Warennes gave St Olave's church, Southwark, to Lewes

\footnotetext{
136 vCH Surrey 1, pp. 285-86.

137 Carlin, Medieval Southwark, p. 135.

138 Carlin, Medieval Southwark, pp. 25-28, 44-46.

139 John Schofield, Medieval London Houses (London, 1995), p. 32; Carlin, Medieval Southwark, pp. 85-89; Bruce Watson, Trevor Brigham, and Tony Dyson, London Bridge: 2000 Years of a River Crossing (London, 2001), p. 94.

140 Carlin, Medieval Southwark, p. 25.

141 VCH Sussex 2, pp. 64-65; for a critical assessment of the-later, but possibly truthfultraditions concerning the priory's origins, see F. Anderson, "Lewes Priory: The Early Sources Re-Examined," in Lewes Priory. Excavations by Richard Lewis 1969-1982, ed. M. Lyne (Lewes, 1997), pp. 5-11.

142 For discussion of the sources, see: John Blair, "The Surrey Endowments of Lewes Priory before 1200," Surrey Arch. Collections 72 (1980), 97-126; the earliest relevant is a confirmation of the priory's possessions by Ralph, Archbishop of Canterbury, in 1121; it is printed in John H. Round ed., Ancient Charters, Royal and Private, prior to A.D. 1200 (London, 1888), pp. 11-16, no. 8; See also $V C H$ Surrey 4, pp. 151-52.

143 Domesday: Sussex, 12:1.
} 
Priory, they re-connected, through their own network of lordship, two places probably connected earlier through the lordship of the Godwin family.

Independent evidence of the early existence of St Olave's in Southwark comes from the Annals of Bermondsey Abbey, which describe a grant of land at Hoddesdon made in 1096 by Petrus de Sancto Olavo to the abbey. ${ }^{144}$ The (Cluniac) abbey was founded in 1082 by a London citizen, and King William I donated the manor of Bermondsey, which had earlier belonged to Harold Godwinson. ${ }^{145}$ The Annals are a 15th-century compilation from diverse earlier sources, in this case, probably, a charter or a confirmation of one (the annal mentions confirmations by William II and Henry I). Peter, the grantor of 1096 was presumably a citizen associated with St Olave's church in nearby Southwark. But the land donated was in Hertfordshire, where he held property in Hoddesdon. Domesday Book described him as "Peter, a burgess," and he held two hides in Hoddesdon from the king which in 1066 had been held by Gode of Queen Edith. ${ }^{146}$ While labelled here "Queen Edith's man," Gode was actually a woman. She and her son had also held from Queen Edith a separate four hides in Hoddesdon as well as two hides in Welwyn. ${ }^{147}$ While Peter's description as "a burgess" may reflect some tenure in nearby Hertford, his link with Southwark and Bermondsey presumably means he was an urban property holder on the south bank of the Thames. By the mid-11th century, Hoddesdon comprised several manorial units. Other interested parties in 1066 were Edeva the Fair and Godith, the man of Asgar the Constable. ${ }^{148}$ In the present context, the succession of the burgess, Peter, to land associated with a member of the Godwin family, is of interest. Perhaps his family had earlier Godwin connections? Perhaps his father was among Earl Godwin's Southwark supporters, mentioned in the Anglo-Saxon Chronicle. Hoddesdon itself was only a few miles from Waltham (Essex), the location of the church patronised by Earl Harold.

William de Warenne was created earl of Surrey by King William II — whom he supported against rebel magnates-early in 1088 but died in June 1088 following a wound at the siege of Pevensey castle. ${ }^{149} \mathrm{He}$ was already one of the

144 The Annals of Bermondsey Abbey, in Annales Monastici, ed. Henry R. Luard, RS 36, 5 vols (London, 1864-69), 3:429.

145 The Annals of Bermondsey Abbey, ed. Luard, pp. xxxv-xxxvi.

146 Domesday: Herts., 42:7.

147 Domesday: Herts., 32:2; 34:4.

148 Domesday: Herts., 16:10; 17:14; 33:13.

149 Ivor J. Sanders, English Baronies. A Study of Their Origins and Descent 1086-1327 (Oxford, 1960), p. 128; Frank Barlow, William Rufus (London, 1983), pp. 73, 93; Christopher P. Lewis, "William De Warenne," in Oxford Dictionary of National Biography, Vol. 57 (Oxford, 2004), pp. 404-06. 
richest men in England, with lands in numerous shires, but his endowments in Surrey came only with the comital title in $1088 .{ }^{150}$ The elevation of William de Warenne was thus linked with the fall of Odo of Bayeux and it seems probable that, in Southwark, there was a sequence of property-holding from Earl Godwin, through Bishop Odo, to Earl William. Thus, unless he had acquired some property in Southwark at an earlier date, the grant of St Olaf's, Southwark, to Lewes Priory could not have been made before 1088. On the other hand, since the major Surrey endowments of William, first earl de Warenne, had been in Queen Edith's hands before 1066, ${ }^{151}$ it is possible that she had a Southwark interest, otherwise undocumented, and had owned — even founded-St Olaf's church there, as suggested by John Blair. ${ }^{152}$ Since the queen was daughter of Earl Godwin and Gytha, however, this possibility further underlines the Godwin family link.

When London Bridge Station was built in 1829-30 and the approach to London Bridge re-built, under-crofts of two 12th-century stone houses close to St Olave's church were discovered. They were subsequently identified, through medieval property records, as belonging to the earls of Warenne and the priors of Lewes. ${ }^{153}$ The possibility should therefore be allowed that the de Warenne house-even though not documented before the 14 th century ${ }^{154}$ - was successor to Godwin's mansio mentioned in the "Life" of King Edward. If this was so, there is an analogy with Exeter: both St Olaf churches stood on a street leading to a major river bridge and both were adjacent to a Godwin family residence. The Southwark house belonging to Lewes Priory may even have been part of the original grant of St Olave's to Lewes Priory. ${ }^{155}$ In 1086, Domesday Book described (above) an interest in Southwark which had been shared between King Edward and the Godwin family. This arrangement survived, emerging as one of Southwark's five medieval manors, and continued to the 14th century. It was known as the Guildable Manor and was not only the earliest, but also the only secular manor: the other four were of 12th-century creation and were

$15^{0}$ VCH Surrey 1, pp. 340-41; and for the family chronicle written in the 12th century, see The Warenne (Hyde) Chronicle, ed. Elisabeth Van Houts and Rosalind Love (Oxford, 2013).

151 Betchworth, Fetcham, Dorking Reigate, Shere; vcH Surrey 1, p. 340; Domesday: Surrey, 1:7; 1:10; 1:12; 1:13.

$15^{2}$ Blair, “The Surrey Endowments of Lewes Priory before 1200," p. 100.

153 G.R. Corner, "Observations on the Remains of an Anglo-Norman Building in the Parish of St Olave, Southwark," Archaeologia 38 (1860), 37-53; John Schofield, The Building of London from the Conquest to the Great Fire (London, 1984), pp. 52-53; Schofield, Medieval London Houses, pp. 31-32, 231-32.

154 Carlin, Medieval Southwark, pp. 28-30.

155 Blair, “The Surrey Endowments of Lewes Priory before 1200," p. 100. 
ecclesiastical manors. Its profits were shared between the kings and the earls of Surrey, whose jurisdictions were separately defined: the royal half was based on High St, while the comital half was based on Tooley St, where St Olave's church and the 12th-century houses found in 1829 were situated. ${ }^{156}$ Thus the manorial geography of Southwark supports the idea, discussed above, of a Godwin-Odo-Warenne succession of interest.

There is, then, no specific evidence that the Southwark church was founded by the Godwins, but, given its location in the manorial geography (above), it seems more likely to have been a Godwin foundation than a royal one (while allowing the possibility of Queen Edith's role, mentioned above). The king's minster mentioned in Domesday Book was presumably St Mary's, founded as the church of the Suthringa geweorc and converted to an Augustinian priory in 1106. It was a parish church from the Reformation and, in 1905, became a new cathedral. ${ }^{157}$ In addition to St Olave's, Southwark's earliest parishes were St George's and St Margaret's, both of whose churches were documented in the early 12th century. St George belonged to Bermondsey Priory and St Margaret belonged to St Mary's Priory in Southwark itself. ${ }^{158}$ St Olave's later became one of Southwark's parish churches. Its territory extended almost a mile eastward from London Bridge and centred on Tooley St, with its cemetery on the north (river-) side of that street. ${ }^{159}$ By 1544 it had a western tower and steeple. ${ }^{160}$ The church was demolished and rebuilt in 1740, repaired after a fire in 1843, and demolished in 1926. The Art Deco building of 1930 occupying the site is called St Olaf's House. ${ }^{161}$ Southwark was, of course, associated with Olaf himself: in his early career, before becoming king of Norway, he had fought in a battle (1014) at London Bridge as an ally of King Æthelred against the Danes. The event was narrated in the 13th-century Saga of St Olaf, with its details embellished by the passage of time. ${ }^{162}$ It seems likely that the church reflects his general popularity rather than any specific memory of this event, though the latter possibility cannot be discounted.

\footnotetext{
156 Carlin, Medieval Southwark, pp. 106-08.

157 VCH Surrey 2, pp. 107-12, for a general history.

158 Carlin, Medieval Southwark, pp. 89, 94.

159 Carlin, Medieval Southwark, pp. 20, Fig. 1, 86.

16o This is shown on Wyngaerde's panorama; Watson, Brigham, and Dyson, London Bridge, p. 94 .

161 Bruce Watson, Old London Bridge Lost and Found (London, 2004), p. 25.

162 VCH Surrey 1, pp. 336-37; Christopher N.L. Brooke and Gillian Keir, London 8oo-1216: The Shaping of a City (London, 1975), pp. 21-22.
} 
London (north of the Thames) had five St Olaf churches, reflecting Scandinavian influence in the city during King Cnut's reign and later. ${ }^{163}$ This influence is normally seen in terms of politics, commerce and social interaction, but it has also been suggested that London churches whose dedications had Scandinavian associations (St Clement Danes and St Bride's as well as the five St Olaf churches) may have been founded specifically by King Cnut to serve garrisons of his Danish troops. ${ }^{164}$ In support of this idea, their locations-near the city walls, the Thames and London Bridge - may be evidence of strategic value. In addition, the hostility of the Londoners to Cnut's conquest is well known. ${ }^{165}$ On the other hand, since most of these churches were dedicated to Olaf (died 1030), they were clearly founded after 1031, by which time London had been ruled by King Cnut for some fifteen years and the "garrison" need could hardly have been urgent. There seem to have been no particular circumstances between 1031 and Cnut's death in 1035 which might have made urban garrisons newly significant. Extension of the 'Danish garrison' idea to York, Exeter, Chester and Chichester-all of which had churches dedicated to St Olaf-suffers the same chronological problem. It must be admitted, however, that all these cities were of strategic significance. In his study of Cnut's reign, M.K. Lawson does not adopt the 'garrison-church' idea and warns that we cannot even be certain that the St Olaf churches in London were founded before Cnut's death. ${ }^{166}$ As we have seen, reference to St Olaf's in Exeter emerges only in King Edward's reign. As a coda to this discussion, it must also be said that the same idea—churches as Danish garrison centres—has also been considered for the forty-plus churches in England dedicated to St Clement (another saint much espoused by the Danish royalty and aristocracy) which are mainly in the towns of the Danelaw. A recent discussion of this issue, however, advises caution, partly because specific supporting evidence is largely absent and partly because the popularity of St Clement in eastern England had begun long before the reign of King Cnut. The strongest case for this argument applies to St Clement Danes church in London, but even here the association with the men of the royal fleet seems to pre-date Cnut's reign. ${ }^{167}$ In the post-medieval period, several Scandinavian churches were built in London, including St Olave's in

\footnotetext{
163 Dickins, "Cult of St Olave," pp. 64-68; Brooke and Keir, London 8oo-1216, pp. 141-42.

164 Pamela Nightingale, "The Origin of the Court of Husting and Danish Influence on London's Development into a Capital City," EHR 102 (1987), 559-78, at p. 567.

165 M.K. Lawson, Cnut. The Danes in England in the Early Eleventh Century (London, 1993), pp. 19-20, 86, 140, 182 .

166 Lawson, Cnut, p. 206.

167 Crawford, Churches Dedicated to St Clement, pp. 3-4.
} 
Bermonsey/Rotherhithe which was consecrated in 1927, a year after the demolition of St Olave's in Tooley St.

\section{Conclusion}

It would be unwise to advance a specifically Olaf-related cult on the part of the Godwins, as opposed to the family's general espousal of an increasingly popular saint. Nevertheless, while the widespread evidence for churches in England dedicated to St Olaf reveals this saint's general appeal, a case can at least be made for the Godwin family endorsing this tradition. Their association with St Olave's church in Exeter is demonstrable. St Olave's church in Southwark is highly likely to have been a Godwin-related foundation, and St Olave's church in Chichester is also likely to have been so (though a case for an alternative origin can be made). It may also be significant that the documentary evidence relating to Exeter concerns - in addition to the patronage of King Edwardspecifically Gytha, Earl Godwin's wife, and that one suggested origin for St Olave's in Southwark is a foundation by Edith, Earl Godwin's daughter. Perhaps the St Olaf cult was particularly favoured, within the family, by their principal women? Here, of course, we must remember that Gytha herself was not only Danish but also related to the Danish royal family (her brother, Ulf, was married to Estrith, the sister of king Cnut) ${ }^{168}$ and that the Danes, despite earlier having been King Olaf's enemy, soon espoused his cause as a saint. Cnut's northern 'empire' provided a background for the spread of people, ideas and fashions in this period. He was not only king of England (1016-35), but also king of Denmark (1018-35) and king of Norway (1028-34).

Of Exeter, the question was asked whether the endowments by Countess Gytha and King Edward were made to a newly-founded church or to a church which had existed earlier, but without landed endowment, in the lifetime of Earl Godwin. It was also questioned whether the multiple dedications of the church were all contemporary, or whether the dedication of St Olaf might have been added to a church already dedicated to SS Mary and Thomas. On balance, the circumstances suggest that all three dedications were contemporary, but the question of whether the church was first founded by Godwin or Harold or Gytha must remain open. Gytha may simply have been up-grading her late husband's foundation, in his memory. At Chichester, dedicated only to St Olaf, there is no evidence to suggest when, in the period concerned, the church was founded. The same applies at Southwark, though a connection with Edith,

168 Mason, House of Godwine, pp. 34-35. 
Godwin's daughter, is a possibility, as noted above. It would be tempting to imagine a neat pattern of family foundations in memory of Earl Godwin: Exeter by Countess Gytha; Southwark by Queen Edith; Chichester-perhaps-by Earl Harold. Our evidence, however, falls short of such a neat conclusion. We must be satisfied with a simpler observation: that the origin of these churches was associated with Earl Godwin's family. Indeed, Godwin himself may have founded all of them, between Olaf's canonization in 1031 and his (own) death in 1053 .

At the places principally discussed here-Exeter, Chichester and Southwark - a case can be made not only for the Godwin family's patronage of St Olaf, but also for their having an urban residence (in addition to urban houses attached to rural manors). Clear evidence links St Olave's in Exeter with the Godwins, but evidence for their urban holdings here is more limited than at Chichester and Southwark, where, in contrast, their link with the St Olave's churches is less clear. Domesday Book, may however, conceal a greater ownership of Godwin family houses in Exeter than is apparent, as we have seen, and the uneven treatment of towns in Domesday Book is well known, so we should not necessarily expect consistent data. Although the recorded references to Irlesbery in Exeter are later in date they represent a reliable tradition of this name in the north-west quarter of the city, where the church dedicated to St Olaf was situated. The strong tradition that Gytha took refuge in Exeter in 1068, and was involved in the city's rebellion against William the Conqueror, supports the idea of a significant family residence here. Whether or not the Godwins had a residence in Chichester, which is probable but not demonstrable, they must have had one nearby at Bosham, which occurs several times in the recorded narratives of the mid-11th century and figures in a famous scene on the Bayeux Tapestry. Given the importance of Southwark to the Godwins, as revealed in the narratives of Edward the Confessor's reign, their possession of a residence there seems beyond doubt. William the Conqueror's recorded burning of Southwark, following his victory at Hastings, may therefore have had not only military significance: it may have been a further deliberate blow against the old order.

That Bosham, Southwark and Dover possessed a 'strategic' value to the Godwins' earldom of Wessex has already been noted. ${ }^{169}$ Dover, on account of its position, was also very important to the kings and their fleets. To these, this discussion has now added Chichester and Exeter. Taken in conjunction with their re-foundation of the minster at Dover, we might also see, in this pattern of data, evidence of the family's combined interest in residences and associated

169 Mason, House of Godwine, p. $5^{2}$. 
churches in key places which were (variously) of political, administrative and commercial importance. Thus, church patronage in the cult of St Olaf was part of the development of these power bases. All these places had coastal, estuarine or riverine situations (as did Topsham, near Exeter, which the family acquired). All were situated in places which had been late Saxon defended burhs: Exeter and Chichester were of Roman origin; Southwark was a new creation of $c .900$ or earlier; Dover was a re-developed Iron Age hill-fort. Exeter and Chichester were amongst the bigger late Saxon towns and all of these places had mints (though varying in output and numbers of moneyers). ${ }^{170}$ Whereas the 1oth-century 're-conquest' of the Danelaw gave rise to newly-created shires named after their shire town, the shires in southern England had a more complex ancestry and not all had an obvious urban centre. ${ }^{171}$ Exeter was, however, clearly the shire town of Devon, as well as a provincial capital for the south west in general. Chichester was, together with Lewes, a principal town of Sussex, as well as close to the Godwins' manor of Bosham, crucial to their maritime activity. Southwark gave the family a base opposite London and near the developing royal centre of Westminster. Southwark was also (with Guildford) notable for its urban character in a shire (Surrey) which experienced little development of early towns. ${ }^{172}$

Finally, a recurrent feature of the data explored in this discussion has been the association of rural manors with urban properties. This reflects not only the general symbiosis of town and country, but also more specific functions that such urban properties might fulfil. These functions, as suggested by various commentators over a long period, could be several. Some urban properties may have had origins in early arrangements relating to urban defensive responsibilities. Some may simply have been occupied by rent-paying tenants of the lords of rural manors. Such properties might well include a house where a rural lord resided when attending courts of shire or borough, or when attending a major minster church situated in the town. These properties may also have been part of the network through which rural produce was sold in urban markets. That these links occur so frequently in Domesday Book reveals that, although town life had developed enormously since the days of the Alfredian

170 For useful information on urban rankings see: Alan Dyer, "Ranking Lists of English Medieval Towns," in The Cambridge Urban History of Britain, Vol. 1: 6oo-1540, ed. David M. Palliser (Cambridge, 2000), pp. 747-70; David Hill, An Atlas of Anglo-Saxon England (Oxford, 1981), p. 130, Fig. 222.

171 James Campbell, "Power and Authority 600-1300," in Cambridge Urban History of Britain, 1, ed. Palliser, pp. 51-78.

172 Martin O'Connell and Robert Poulton, "The Towns of Surrey," in Anglo-Saxon Towns in Southern England, ed. Jeremy Haslam (Chichester, 1984), pp. 37-51. 
burhs, it had not yet become quite as distinct from rural life as it was to be in later centuries. Another indicator of town-country links in the 11th century is the ongoing cultivation by townsfolk of agricultural land around their towns. Exeter, one of the places analysed in this discussion, was, in fact, a case in point at this time, as Domesday Book reveals. ${ }^{173}$

\section{Acknowledgements}

I am grateful to John Allan, Stuart Blaylock, Richard Parker and Andrew Pye for advice on the north-west quarter of Exeter; to Nicholas Orme, for sharing his work on St Olave's, Exeter, before its publication (when I was concurrently researching the Godwins' Irlesbery site); to Julia Crick, for helpful discussion of various sources; to Bill Woodburn, Joan Langhorne and Fred Aldsworth for help with Bosham and Chichester; to Rhodri Lewis (West Sussex Record Office) for answering my Sussex queries; to Karl Alvestad (University of SouthEastern Norway) for help with medieval sources on Norway, bishop Grimkel and St Olaf in Norway; to John Schofield and Martha Carlin for help on Southwark; to the staff of Devon Heritage Centre (formerly Devon Record Office) and Exeter Cathedral Archives. John Allan, Julia Crick and Nicholas Orme made helpful suggestions when the text was at draft stage. The majority of drawn illustrations were prepared by Oliver Creighton, to whom I am most grateful.

173 Allan, Henderson and Higham, "Saxon Exeter," pp. 385-411. 